\title{
TEXTILIE Z TUMBY SV. VÁCLAVA
}

\section{MILENA BRAVERMANOVÁ - HELENA BŘEZINOVÁ - JANA BUREŠ VÍCHOVÁ}

\begin{abstract}
Abstrakt: Ve sbirkách Pražského hradu je uložen cenný soubor textilii pocházejících z tumby sv. Václava († 935). Ostatky knížete byly ze Staré Boleslavi na Pražský hrad přeneseny nékolik let po jeho smrti a uloženy do jižni apsidy rotundy sv. Vita. Hrob se nacházel po staleti stále na stejném místě, ve středověku došlo k vybudováni nadzemni tumby a oltáře, které byly dále několikrát upravovány. Ostatky spolu s inventárem, předevšim textiliemi, byly vyzvednuty v roce 1911, a to jak z oltáře, tak z olověné truhly nacházejicí se pod úrovní podlahy. Celkem 18 tkanin bylo restaurováno v letech 2002-2003, byl proveden textilně technologický průzkum a v letech 2018 a 2019 došlo i kjejich celkovému novému vyhodnocení. Tkaniny pocházejí z širokého období, a to od 11.-12. století až po 15. století. Největši množstvi jich je ze 13.-14. století. Oblasti, kde byly zhotoveny, se nacházeji ve všech tehdejšich hedvábnických centrech, a to v severní Č́ně, ve Střední Asii, na Předním východě, v Egyptě, ve Španělsku a Itálii. Nejstař̌i z látek byla utkána technikou samitum, ostatní jsou lampasy. Nevzorované textilie jsou ve vazbě plátnové nebo keprové. Látky pocházející z tumby sv. Václava jsou druhotnými relikviemi, neboli předméty, které se dostaly do kontaktu s ostatky světce.
\end{abstract}

Klíčová slova: Pražský hrad-sv. Václav-samitum - lampas - relikviářové tkaniny.

\section{Fabrics from the tomb of St. Wenceslas}

Abstract: The Prague Castle collections hold a precious series of fabrics from the tomb of St. Wenceslas (†935). The remains of the prince were transferred to Prague Castle from Stará Boleslav several years after his death, and were interred in the south apse of St. Vitus Rotunda. For centuries, the grave remained in the same place. In the Middle Ages an above-ground tomb and altar were constructed, later modified several times. The remains and the grave goods, mostly fabrics, were removed from the altar and the lead tomb situated underneath the floor in 1911. In total, 18 fabrics were restored in 2002-2003, textile and technological analyses were conducted, and in 2018 and 2019 the items were newly assessed. The fabrics come from a broad period spanning the 11th/12th century and the 15th century. Most fabrics date from the 13th-14th century. The regions in which the fabrics were produced are located in all major silk-making centres of the time: north China, central Asia, the Near East, Egypt, Spain and Italy. The oldest fabric was woven with the samitum technique, the others are lampas fabrics. The fabrics without patterns are in plain or twill weave. The fabrics from the tomb of St. Wenceslas are secondary relics, i.e. objects which were in contact with the saint's remains.

Key words: Prague Castle - St. Wenceslas - samitum - lampas - reliquary fabrics.

\section{1 Úvod}

Ve sbírkách Pražského hradu je uložen cenný soubor textilií pocházejících z tumby sv. Václava. Z tumby byl vyjmut a částečně zapsán do Chrámového pokladu již v roce 1911 (inv. č. K 431, 432; Podlaha 1911). V roce 1985 byla tato část nevhodně restaurována ve Státních restaurátorských ateliérech (1985), jejich předběžné zhodnocení následně provedla N. Bažantová (1996, 19-51). ${ }^{1}$ V roce 2000 byla nalezena druhá část souboru ve skříni v bývalém prostoru Kapitulní knihovny v Házmburské kapli, která se nachází v přízemí Velké věže. Nejprve však nebylo zřejmé, že tyto látky přináleží ke svatováclavským textiliím zapsaným v Chrámovém pokladu. To se ukázalo v roce 2002, kdy jejich textilně technologický průzkum provedla K. Spittel (2002). V roce 2003 probíhalo nové restaurování látek z Chrámového pokladu a při té př́ležitosti se $\mathrm{k}$ nim přiřadil i soubor nalezený v Házmburské kapli (Otavská 2003). ${ }^{2}$ Všechny textilie byly adjustovány společně (inv. č. PHA 2/1). ${ }^{3}$

\footnotetext{
1 Základní textilně technologický průzkum provedla A. Samohýlová.

2 Soubor textilií byl z nyní neznámého důvodu rozdělen na dvě části zřejmě již v době vyjmutí z tumby v roce 1911, přičemž na část uloženou v Házmburské kapli se postupem času zapomnělo.

3 HS10996, HS25781, HS25782, HS25783, HS25784, HS25785, HS25786, HS25787, HS25788, HS25789, HS25790, HS25791, HS25792, HS25793.
} 
V rámci současného celkového zpracování všech textilií z archeologických kontextů na Pražském hradě bylo přistoupeno rovněž ke zhodnocení celého souboru tkanin z tumby sv. Václava. Byla provedena jak revize starších závěrů, tak nová interpretace - ta je předmětem předkládaného článku.

\section{Hrob sv. Václava}

Kníže Václav byl zabit v roce 935 na hradišti ve Staré Boleslavi. Události, které po jeho zavraždění bezprostředně následovaly, s menšími odchylkami popisují legendy. Podle Crescente fide bylo tělo sv. Václava „(...) chvatně uloženo do hrobu (...)“ (Utrpení sv. Václava mučedníka 187, bavorská recenze; Ludvíkovský 1958, 61, česká recenze). ${ }^{4}$ První staroslověnská legenda uvádí podrobnější záznam: „,[tělo sv. Václava] (...) kněz Krastěj vzal a položil před chrámem a zakryl jej tenkým plátnem. A jeho matka, když uslyšela, že její syn byl zavražděn, hned přispěchala a hledala ho. A spatřivše jej, klesla na jeho srdce. A s pláčem sbirala údy těla jeho, svého syna. A když ho sebrala, neodvážila se ho nést do svého domu. Ale umyvše a obléknuvše jej na dvoře knězově, odnesli ho a položili v kostele (...). Potom povolali kněze jménem Pavel, aby nad ním vykonal modlitbu. A pohřbili úctyhodné tělo, (...)“(Bláhová-Konzal 1976, 120, minejní redakce; Bláhová-Konzal 1976, 72, Vostokovova redakce). Podle Gumpoldovy (Gumpoldův život Václava knížete českého, 161) a Druhé staroslověnské legendy (Bláhová-Konzal 1976, 172) „(...) uzavřeli pak svaté tělo uctivě do rakve, a vykonavše nad ním předepsané obřady, pohřbili ho před kostelem, pobliž mista vitězství (...)“. Kristiánova legenda zaznamenává: „(...) bezduché tělo matka (...) s některými věrnými sebrali, a toliko do hrobu je položivše, zemí je zasypali (...)“ (Pekař 1906, 115). Podle Vavřince „(...) mrtvé tělo leželo po nějaký čas nepohřbeno v témž chrámě, kde dotrpěl (...)“(Vavřince, mnicha sv. Benedikta Utrpení sv. Václava, 178).

Přestože popisy se poněkud různí, je možné se domnívat, že první místo posledního odpočinku knížete Václava se snad nalézalo v kostele sv. Kosmy a Damiána a bylo velmi prosté. Přes všechny nové objevy na hradišti ve Staré Boleslavi zůstal zatím tento kostel archeologicky nedoložen (Boháčová 2010, 168).

První staroslověnská legenda dále uvádí, že Václavova krev třetí den zmizela a „(...) vystoupila v chrámě nad ním (...)“ (Bláhová-Konzal 1976, 120, minejní redakce, BláhováKonzal 1976, 72, Vostokovova redakce). Asi tím byl míněn jakýsi baldachýn uvnitř kostela (Cibulka 1934, 368-369) anebo hrobová kaple, která by v tomto případně musela stát vně kostela (Sommer 2000, 242-243). Tuto možnost Gumpoldova a Druhá staroslověnská legenda naznačují.

K době, kdy ostatky sv. Václava ještě spočívaly ve Staré Boleslavi, se váže zmínka v Kristiánově legendě o tom, že po čase Václavova sestra Přibyslava hrob otevřela a přidala k mrtvole ut'até bratrovo ucho (Pekař 1906, 118-119). Podobnou historku popisuje Vavřinec, mělo se ale jednat o ruku (Vavřince, mnicha sv. Benedikta Utrpení sv. Václava, 178). ${ }^{5}$

Po určité době byly ostatky sv. Václava z podnětu bratra Boleslava I. ze Staré Boleslavi přeneseny do rotundy sv. Víta na Pražském hradě. V legendách Crescente fide (Utrpení sv. Václava mučedníka, 187, bavorská recenze; Ludvíkovský 1958, 62, česká recenze), Gumpoldově (Gumpoldův život Václava knížete českého, 161), Kristiánově (Pekař 1906, 116) a Druhé staroslověnské legendě (Bláhová-Konzal 1976, 172) je napsáno, že k tomu došlo za tři roky. Naopak Vavřinec spojuje přenos až s dobou episkopátu sv. Vojtěcha (Vavřince, mnicha sv. Benedikta Utrpení sv. Václava, 179). Translace probíhala v noci a došlo $\mathrm{k}$ ní - zdá se - bez př́ítomnosti církevních autorit. Jediný, kdo uvádí, že se přenosu účastnil biskup - a to sv. Vojtěch -, je opět Vavřinec.

D. Třeštík spojil translaci až se snahami o zrrízení pražského biskupství a posunul ji do 60 . let 10. století (např. Třeštík 2002, 314), objevují se však i názory, že to bylo o něco dříve, například na začátku 50. let (např. Kubín 2011, 139-141).

4 České překlady citací pramenů byly převzaty z těchto publikací: Hrdina-Bláhová 1972; Chaloupecký 1939 ; Králík 1969.

5 D. Třeštík doložil, že „ucho“v Kristiánově legendě je důsledkem špatného přečtení místa v původní, dnes ztracené, předloze (1997, 225-229). 
Na Pražském hradě byl sv. Václav pohřben do rotundy sv. Víta, kterou sám založil. V legendě Crescente fide je napsáno, že tělo bylo pohřbeno v rakvi „vedle oltář ““ (Utrpení sv. Václava mučedníka, 188, bavorská recenze; Ludvíkovský 1958, 62, česká recenze), podle První staroslověnské legendy „(...) po pravé straně oltáře 12 apoštolů, který sám vybudoval (...)“(Bláhová-Konzal 1976, 121, minejní redakce; Bláhová-Konzal 1976, 73, Vostokovova redakce). Gumpoldova legenda zaznamenává, že sv. Václav byl pohřben za jásavého zpěvu lidu a kněží ,před samým oltářem" (Gumpoldův život Václava knížete českého, 162), Druhá staroslověnská legenda doplňuje, že tomu bylo „na jižni straně přimo pod oltár̆ní stupne““ (Bláhová-Konzal 1976, 174). Kristiánova legenda uvádí, že sv. Václav byl pohřben „, rakvi v bazilice“ (Pekař 1906, 119). Trochu jiný údaj má Vavřinec, který poznamenává, že tělo sv. Václava bylo uloženo „(...) ve stř́brné rakvi v chrámu sv. Víta (...), vedle oltáře téhož mučedníka (...)“ (Vavřince, mnicha sv. Benedikta Utrpení sv. Václava, 180).

Podle všeho se tedy zřejmě zahloubený světcův hrob nacházel ve svatovítské rotundě v jižní apsidě podkovovitého tvaru. To, že se jednalo o hrob vyhloubený v zemi, snad dokazují nálezy z roku 1911, a to nejenom stavebně historický průzkum místa, ale i obsah pozdější gotické rakve, do níž byla uložena nápisem označená „,prst““ z původního Václavova hrobu (Podlaha 1911).

Po výzkumu provedeném v roce 1911 se za zbytek původního Václavova hrobu, jak napsal K. Hilbert, považovala „(...) mělká prohlubeň nacházející se pod současným Václavovým hrobem (...)“. Dále se předpokládalo, že oltář dvanácti apoštolů nezměnil po celou dobu svoji polohu (Hilbert 1934, 222, 228). Na základě revize všech pramenů dnes existuje poněkud odlišná interpretace. První etapou svatovítské rotundy byla stavba lodi s východní apsidou. Ve druhé etapě byla pro uložení ostatků sv. Václava zřízena jižní apsida a snad první oltář dvanácti apoštolů. Třetí stavební etapou, pravděpodobně za episkopátu biskupa Šebíře (biskupem od roku 1030, zemřel 1067), bylo zbourání vnitřního prstence jižní apsidy a vybudování nového vnějšího obvodového zdiva. Prstencový tvar apsidy se tak o něco zvětšil. Hypoteticky je možné uvažovat i o tom, že třetí fázi by bylo možné spojit se snahami o ustanovení pražského biskupství, i když tato aktivita není písemně doložena. Na korunu severovýchodního ramene nezbořené části starší rotundy byl tehdy umístěn základ nového oltáře dvanácti apoštolů. Ve čtvrté etapě, nadále za Šebíře, došlo ke změnám v interiéru jižní apsidy, především byla snížena úroveň podlahy a byla pořízena nová omítka. V páté etapě, stále ještě za Šebířova episkopátu, byla apsidální kaple od lodi oddělena příčkou (Frolík a kol. 2000, 145-209). Přestože za těchto stavebních etap došlo v apsidě k různým činnostem, o samotné úpravě hrobu nemáme žádnou zprávu.

Jižní apsida svatovítské rotundy je od roku 1911 špatně př́stupná, a proto ověřit nálezovou situaci, tak jak ji zanechal K. Hilbert, je složité. Je však zřejmé, že s oltářem dvanácti apoštolů K. Hilbert ztotožnil blok zdiva dochovaný na zdivu vnitřního prstence. Toto hypotetické zdivo je však vzhledem k poloze bloku mladší. Pokud se zbytek nejstaršího oltáře dochoval, je dnes ukryt na fragmentu zdiva lodi a pod základem gotického oltáře (Frolík a kol. 2000, 198).

Samostatnou otázkou je existence oltáře zasvěceného prŕímo sv. Václavu, který v souladu se zvyklostmi vážícími se ke světeckým hrobům mohl být s hrobem svatého knížete propojen. J. Cibulka s tímto oltářem počítal, podporou mu byly především údaje v Gumpoldově a Druhé staroslověnské legendě. Oltář sv. Václava umístil v ose apsidy do pozadí za jeho hrob (Cibulka 1934, 387-388). Problémem je, že J. Cibulka, který převzal údaje K. Hilberta, považoval vnitřní prstenec zdiva jižní apsidy za mladší, a nikoliv za starší. Do starší menší apsidy by se tento oltář, pokud by byl zděný, nevešel, nanejvýše by se mohlo jednat o oltář přenosný. Pokud ale autoři Gumpoldovy a Druhé staroslověnské legendy měli na mysli skutečně zděný oltář sv. Václava, potom bychom výstavbu vnějšího prstence apsidy museli datovat do doby okolo zřízení biskupství, a nikoliv až do doby Šebířovy. To však odporuje údaji v Kosmově kronice, kde je jako původce stavebních úprav apsidy uveden Šebíř (Kosmas, 228). Situaci je možné uzavřít domněnkou, že v první fázi u hrobu sv. Václava jemu zasvěcený oltár̆ pravděpodobně nestál. 
V době, kdy se již začala šířit pověst o novém pražském světci, měla sestra sv. Václava Přibyslava s dalšími pomocníky oddělit od ostatků čelist a v dílech ji rozdat sobě a přátelům jako relikvie. Za to byli podle Kristiánovy legendy stiženi „pomstou Božzi“" (Pekař 1906, 124).

Kolem poloviny 11. století rotunda sv. Víta již nevyhovovala nárokům na biskupský kostel a postupně ustoupila bazilikální novostavbě. Hrob sv. Václava byl ponechán na místě, kolem byla postavena nová kaple nacházející se při jižní straně východního chóru baziliky. Při úpravách byla zvýšena úroveň terénu, odbourán prstenec apsidy i prríčka oddělující původní kapli. Na zvýšené podlaze byl zrrízen nový oltář dvanácti apoštolů. Nadále však nemáme žádnou zprávu o jakékoliv úpravě hrobu sv. Václava (Frolík a kol. 2000, 202).

Konkrétní zmínka o místu posledního odpočinku sv. Václava se v Druhém pokračovateli Kosmy vztahuje až k roku 1245, kdy oltář nad hrobem sv. Václava byl opraven a nově konsekrován (Druhé pokračování Kosmovo, 285). Jak dosvědčují ve 20. století v tumbě sv. Václava nalezené textilie, na místo světcova posledního odpočinku se tehdy dostaly i drahocenné látky.

Za Lucemburků byla hrobu sv. Václava věnována, až na několik výjimek, mimořádná



Obr. 1. Pohled na zbytky gotického náhrobku sv. Václava. a - podzemní část; b - nadzemní část. Podle Podlaha 1911.

Abb. 1. Blick auf die Überreste des gotischen Grabmals des hl. Wenzel. a - unterirdischer Teil; b-oberirdischer Teil. Nach Podlaha 1911. péče. Podle Beneše Krabice z Weitmile nechal Karel IV. k okrase místa zhotovit sochy dvanácti apoštolů (Beneš Krabice z Weitmile, 488). Jan Lucemburský je sice $\mathrm{v}$ roce 1336 dal v zástavu svým věřitelům (Beneš Krabice $\mathrm{z}$ Weitmile, 332, 423, 488), ale již $\mathrm{v}$ roce 1341 listinou ustanovil, aby veškeré stř́ibrné doly v Čechách odváděly kapitule u sv. Víta desátek z důchodů, jejž byly povinny dávat královské komoře. $\mathrm{Z}$ toho měly být zbudovány skvostné hroby sv. Václava a sv. Vojtěcha se stříbrnými deskami, pozlacenými sochami, kamejemi a drahokamy (Eršil-Pražák 1956, č. 184).

K zásadní úpravě světcova hrobu, vyjmutí jeho ostatků-kromě nejpozději v roce 1305 oddělené lebky (Petra Žitavského Kronika zbraslavská, 94) - a k jejich novému uložení došlo mezi lety 1346-1348. Při průzkumu místa v roce 1911 se zjistilo, jak toto nové aranžmá vypadalo (obr. 1). Pod úrovní podlahy pod kamennou deskou byla vložena olověná truhla s vyjmutou hrobovou prstí a zbytky dřevěné rakve z předpokládaného původního světcova hrobu. Do této truhly byla vložena i menší olověná truhlice, vyplněná dřevěnou skřriňkou potaženou kůží. Nad úrovní podlahy byla zřízena dřevěná domečkovitá schrána, umístěná na oltáři (Podlaha 1911). Schrána i oltář byly zdobené polodrahokamy, kamejemi, perlami a zlatými pláty (Podlaha-Šittler 1903, inventář z roku 1354, zápis č. 26; inventáŕ z roku 1355, zápis č. 124). Manželky Karla IV., ale i pražští měštané také $\mathrm{v}$ té době hrob obdarovávali šperky, kříži, čalouny, př́íkrovy a paramenty (Podlaha-Šittler 1903, inventáŕ z roku 1354, zápisy č. 90, 206, 207, 231). 
V roce 1366 byla jako součást katedrály dostavěna gotická kaple sv. Václava a při té př́iležitosti byl zřízen i nový oltář - oltáři z roku 1348 byla odbourána mensa až ke kamenným deskám chránícím spodní část hrobu. V roce 1367 došlo $\mathrm{k}$ vysvěcení nového oltáře, jak to dosvědčuje listina Jana Očka z Vlašimi nalezená v roce 1911 (Podlaha 1911, 9). V inventáři Svatovítského chrámu z roku 1387 se dochoval záznam popisu nové tumby. Byla to obdélníková hranolovitá skřŕň se stř́íškovitým víkem, na čelní straně bylo poprsí Karla IV. a jeho manželky vyřezané v sardonyxech s korunkami ze zlata, perel a drahokamů, nad nimi soška sv. Václava v rukách držící kopí s praporcem a štít. Vše bylo zdobeno rubíny, safíry, perlami, kamejemi a moniliemi. Též plochy mezi reliéfy byly posázeny moniliemi. Severní obdélná stěna tumby byla pokryta osmnácti umělecky ztvárněnými deskami s reliéfy ve třech řadách nad sebou. Počítalo se i se zasazením deskovité schrány pro zlomek domnělého autografu evangelia sv. Marka. Tumba byla pokryta vodorovným víkem s kamejemi a křížkem a dále stř́iškovitým víkem opět s reliéfy. Jižní a západní strany tumby byly bez ozdob, pokryté pouze zlatými pláty (Podlaha-Šittler 1903, inventář z roku 1387, Tumba scti Wenceslai, LIII-LVI).

I v dalších letech jsou v inventáŕích Svatovítského chrámu zmiňovány drahocenné dary, které byly věnovány hrobu českého patrona. Opět to byly především textilie (Podlaha-Šittler 1903, inventář z roku 1396, zápis č. 158).

Od konce 14. století po následující období začalo docházet k poškozování tumby, materiál z ní často sloužil k úhradě různých výdajů. Např́ílad Jan Zhořelecký chtěl za utržené peníze vyplatit svého bratra Václava IV. ze zajetí, pro všeobecné pohoršení ale skvosty vrátil. Zkázu obložení tumby završil v roce 1420 král Zikmund, který její velkou část zcizil. To už bylo obložení tumby na Karlštejně, kam jej nechal v roce 1411 převézt Václav IV. Do roku 1425 byl zbytek výzdoby rozkraden. Od té doby stála ve svatováclavské kapli holá schrána, překrytá pravděpodobně jenom pokrývkami (Podlaha-Šittler 1903, inventář z roku 1420, Inventarium rerum in capella s. Wenceslai; inventář z roku 1496, Inventarium rerum capellae sancti Venceslai).

Požár roku 1541 ostatky sv. Václava nezasáhl, bylo ale poničeno okolí tumby. Domečkovitá schrána byla tehdy zřejmě vložena do kamenného podstavce oltáře a překryta deskou, nebot' plameny ostatkům neuškodily (Beckovský 1880, 97). Další nepříznivou událostí, která se dotkla okolí svatováclavské tumby, bylo řádění kalvinistů v katedrále v roce 1619. Alespoň ty nejhorší ztráty se po opětovném nastoupení snažili odstranit habsburští panovníci a prŕslušníci jejich rodiny pomocí darů (Berghauer 1761, 100; Pešina z Čechorodu 1673, 110).

$\mathrm{V}$ roce 1671 nechal arcibiskup Matouš Ferdinand Sobek z Bilenberka mensu původního oltáře obložit bílým a červeným mramorem a do ní vložit větší nově zhotovenou dřevěnou truhlici s ostatky (Podlaha 1911). Oltáŕ byl tehdy vyzdoben stř́ibrnými svícny a sochami andělů a sv. Václava, v zadní části byl oltářní nástavec se zasklenou schránkou pro přilbu sv. Václava. Na oltáŕi také stál tabernákl z drahokamů, práce rodiny Misseroniů (Berghauer 1736, 121-122). V roce 1806 byly svícny a socha prodány do mincovny, místo nich byly na oltáŕ postaveny sochy dřevěné. Chudou úpravu místa posledního odpočinku českého patrona částečně změnil světící biskup Karel Průcha. V roce 1881 dal zrrídit nový stř́zilivý oltářní nástavec a na něj postavil dřevěnou polychromovanou sochu světce (Podlaha 1911).

Situace se obrátila až na začátku 20. století. V roce 1905 probošt svatovítské kapituly Antonín Hora věnoval větší peněžní obnos na novou tumbu a oltář sv. Václava. Proto došlo v roce $1911 \mathrm{k}$ otevření oltáře. Byl též proveden stavebně historický průzkum celého místa a poté i antropologický průzkum světcových ostatků (Podlaha 1911). Podle návrhu Kamila Hilberta byl v letech 1912-1913 na nalezených zbytcích gotické oltářní mensy a tumby postaven nový oltář, který je pokusem o rekonstrukci původního stavu. Oltář stojí na západní části náhrobku, východní část je podložena schodem sestaveným z kusů starého kamene, spodní část náhrobku je podle středověkého vzoru obložena leštěnými kameny pocházejícími ze starých surovin. Na náhrobku stojí nová dřevěná domečkovitá schrána (obr. 2). Tato úprava přetrvává dodnes. 


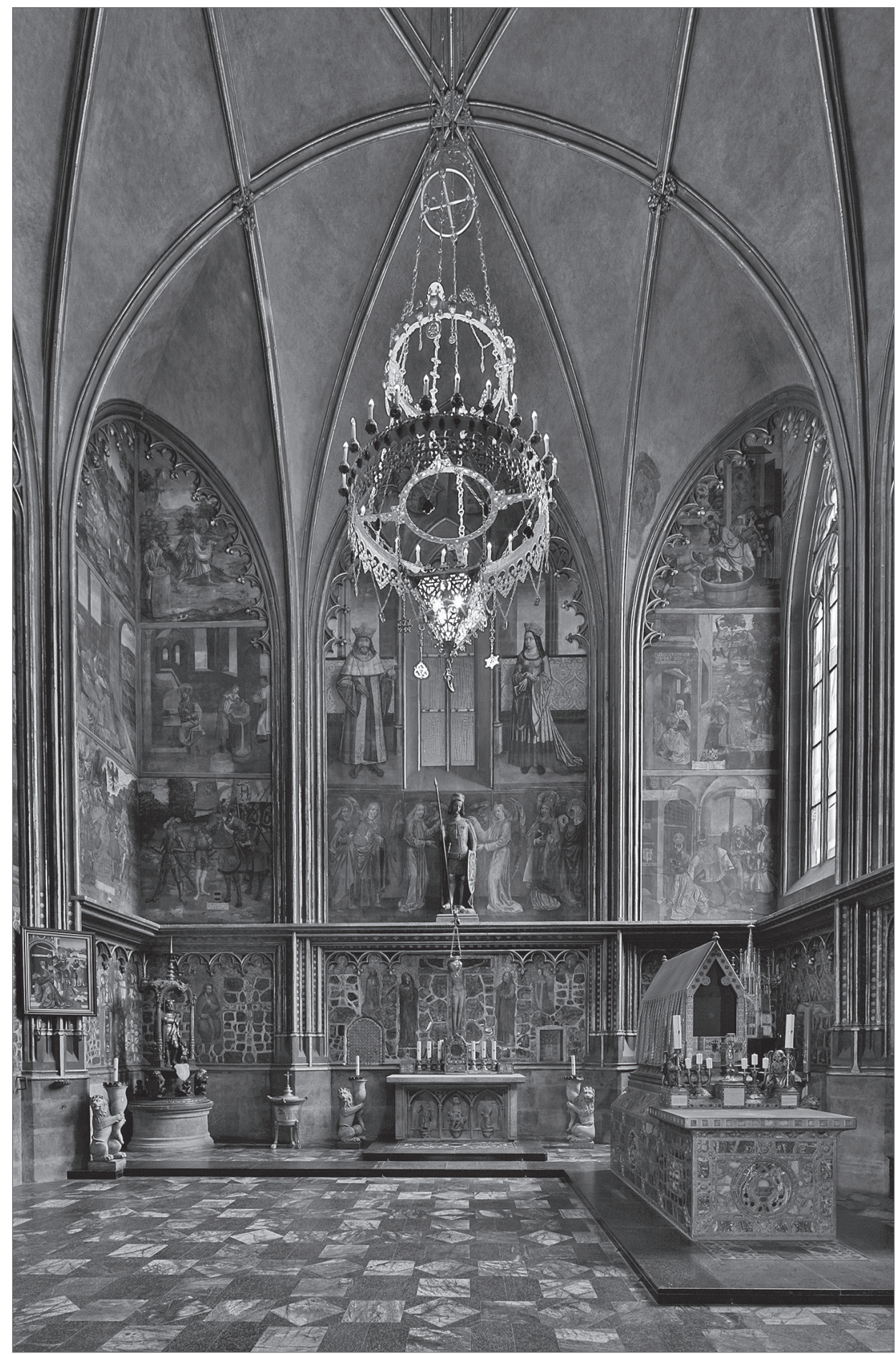

Obr. 2. Kaple sv. Václava, současný stav. @ Správa Pražského hradu, foto J. Gloc.

Abb. 2. St. Wenzelskapelle, gegenwärtiger Zustand. (C) Verwaltung der Prager Burg, Foto J. Gloc. 


\section{Inventár̆ hrobu}

Část inventáře byla vyzvednuta 4. dubna 1911, kdy došlo k otevření oltáře. Další část potom 29. dubna téhož roku, kdy byl prozkoumán obsah olověné truhly, nacházející se pod úrovní podlahy.

\section{Vnitřní prostor oltáře}

Ve vyzděném prostoru oltáře se nalezly zbytky prken z truhlice pořízené v roce 1671 a gotická domečkovitá schrána o přibližných rozměrech: délka $40 \mathrm{~cm}$, šířka $20 \mathrm{~cm}$ a výška $20 \mathrm{~cm}$. V ní se nacházely ostatky. Vnitřek schrány měl být potažen nevzorovanou hedvábnou látkou světlehnědé barvy. Zvnějšku měla být schrána zahalena žlutozelenou „damaškovou“ látkou, která splývala a pod dnem byla spojena pomocí kroužků a provlečené šňůrky. Dále se nalezla malá olověná krabička se zetlelými zbytky relikvií obalená pergamenovou konsekrační listinou s pečetí Jana Očka z Vlašimi z roku 1367. Též byla vyzvednuta pozdně renesanční skleněná relikviářová schrána zdobená náboženskými motivy, kterou v roce 1671 do oltáře vložil arcibiskup Sobek. Ten také do prostoru oltáře vložil látkový váček s ostatky sv. Lazara z Betánie, sv. Ananiáše, sv. Klementa a sv. Blažeje, které v roce 1370 z Mantovy přivezl Karel IV.

Tkaniny, ležící na troskách truhlice pořízené arcibiskupem Sobkem, byly charakterizovány jako renesanční a popsány takto (Podlaha 1911, 30):

a) látka červená se žlutým vzorem granátového jablka,

b) látka tmavohnědá s tmavozeleným vzorem granátového jablka,

c) látka hnědožlutá s tmavozeleným vzorem, v němž mimo rostlinné stylizované prvky jsou symetricky proti sobě postavené labutě a delfíni,

d) látka tmavozelená se žlutým vzorem úzkých pruhů oddělených od sebe řadou srdcovitých lupenů, v pruzích se střídají dva různé ornamenty rostlinné,

e) látka hnědožlutá s tmavozeleným vzorem, základní motiv je makovice,

f) malý kousek červené látky s pletencovým motivem.

\section{Podzemní olověná truhla}

Olověná truhla o přibližné délce $200 \mathrm{~cm}$ a šiřce $70 \mathrm{~cm}$, na obou koncích opatřená zámky, se nacházela ve vyzděném podzemním prostoru. Na jejím víku byla položena olověná nápisová destička z roku 1348 sdělující, že ve schráně se nachází prst' sebraná z původního hrobu světce. Truhla byla zaplněna hlínou s úlomky dřeva, uprostřed se nacházel malý „hrůbek“ ohraničený čtyřmi kameny. $Z$ něj vyčnívala malá olověná truhlice o délce $44,5 \mathrm{~cm}$, šířce $27,5 \mathrm{~cm}$ a výšce $31,5 \mathrm{~cm}$. Víko bylo připevněno pomocí závěsů a petlice. Pod ním byla stř́brná destička též z roku 1348 oznamující, že zde jsou kosti a prach sv. Václava, „sebrané v zemi tohoto hrobu“. Truhlička byla vyplněná drobnými kůstkami, hlínou, dřevem a zbytkem jakési dřevěné skřŕňky, kdysi potažené kůží. Mezi nálezy byly i mince Přemysla Otakara II. a Václava II. a pečet' Arnošta z Pardubic. Fragmenty červené a nahnědlé hedvábné tkaniny shodné s látkami nalezenými v domečkovité schráně v oltářním prostoru svědčí o tom, že ostatky byly ve stejnou dobu rozděleny do hrobní dutiny nacházející se pod oltářem a do schrány postavené na oltár (Podlaha 1911).

\section{Textilně technologický rozbor textilií ${ }^{6}$ jejich interpretace}

V letech 2002-2003 bylo restaurováno čtrnáct tkanin pocházejících z tumby sv. Václava (viz 4.1 až 4.11), dále textilní váček s podšívkou (viz 4.12), do kterého byly vloženy ostatky sv. Lazara,

6 Detailní textilně technologický rozbor textilií je uveden v př́iloze na konci článku. 
sv. Ananiáše, sv. Klementa a sv. Blažeje původně zřejmě zabalené do dalších dvou látek (viz 4.13; Spittel 2002; Otavská 2003).

Základem odborného zpracování archeologických textilií je provedení textilně technologického průzkumu, který zahrnuje technologický rozbor a podrobnou dokumentaci. Následuje jeho vyhodnocení, shromáždění soudobých analogií a zasazení do celkového rámce dobové textilní výroby. V závěrečné interpretaci jsou též zapracovány historické zprávy týkající se předmětu výzkumu (k metodologii viz Bravermanová-Březinová-Urbanová 2011).

Nově provedené vyhodnocení textilií z tumby sv. Václava je součástí systematického průzkumu a publikace archeologických textilií v ČR, které jsou zde prováděny v posledních dvaceti letech a jsou plně v souladu s evropským bádáním (Bravermanová-Březinová 2017).

\subsection{Tkanina s pletencem, palmetami, perlovcem a zvířaty (obr. 3)}

Zachovala se v osmnácti fragmentech, z nichž největší (č. 1) má výšku $12,8 \mathrm{~cm}$ a šiřku $28,5 \mathrm{~cm} .^{7}$ Tkanina je hedvábné samitum, kdy nitě hlavní osnovy leží mezi vrstvami útků a vazná osnova provazuje par passée v keprové vazbě $1 / 2$ Z ${ }^{8}$ Vzorování je tvořeno třemi systémy útků.

Samitum bylo bohatě od jednoho kraje k druhému kraji tkaniny protkávané kovovým lancé útkem, naproti tomu zelený (případně hnědý) broché útek se objevuje jenom v některých detailech vzoru.

Jedno z nejstarších samit (keprová vazba 1/2 S) s drobným geometrickým vzorem pochází z byzantského prostředí a je datováno již do přelomu 10. a 11. století. Na vzoru se podílejí jak kovový broché útek (pozlacený proužek živočišného podkladu obtočený kolem hedvábné duše), tak hedvábné lancé útky (Siftskirche St. Michal, Beromünster; Schmedding 1978, 29). Shodně je tomu i u samita (keprová vazba 1/3 S) z relikviáŕového hrobu sv. Amanda z baziliky sv. Petra v Salzburgu. Látka, na níž je vzor medailonu s dvojhlavým orlem, je určena jako západoasijská/ seldžucká z 11. až začátku 12. století (Abegg-Stiftung, Riggisberg; Otavský-Wardwell 2011, 163-167). Vzorující útky jsou shodné i u samita (keprová vazba 1/2 S) se srdčitými medailony vyplněnými dvojhlavým orlem. Látka je určena jako anatolská z první třetiny 13. století (Kunstgewerbemuseum, Berlin; Wilckens 1992, 43-44). Obdobnou technikou bylo zhotoveno samitum (keprová vazba $1 / 2 \mathrm{~S}$ ) s pěti systémy útků, z nichž tři jsou broché. Látka je interpretována jako sicilská z druhé poloviny 12. století (Sbírky Pražského hradu, Praha; Bravermanová-Otavská 2000, 409-432).

Vzor v celistvosti nelze vzhledem k současné fragmentárnosti tkaniny s pletencem, palmetami, perlovcem a zvířaty určit, protože se z něj zachovaly jenom některé detaily. V každém případě jde o větší vzorový raport, jehož velikost dnes nelze stanovit. Na největším fragmentu (č. 1) jsou efektem červenohnědého ${ }^{9}$ útku vytkané obrysové linie, výplň ploch mezi liniemi je vytvořena efektem kovového útku. Patrné jsou dvě symetricky proti sobě postavené a do oblouku zatočené linie, mezi nimiž je perlovec. Ve vodorovném směru jsou dva symetrické útvary tvořené rovnými linkami, mezi nimiž jsou těsně na sebe navazující srdcovité útvary. Pod těmito útvary jsou dvě symetricky umístěné zatočené linie, v jejichž blízkosti se nalézá malý kulovitý útvar (oko?) provedený broché efektem hnědého útku. Vzor na tomto fragmentu může připomínat dvojici k sobě obrácených zvířat s postroji (sloni?). Na dvou fragmentech tkaniny (č. 2, 18) jsou efektem kovového a červenohnědého útku vytkány palmety s pletencem, na dalším (č. 9) je broché efektem zeleného útku vytkána část obvodu kruhového medailonu s perlovcem. Na zbylých fragmentech jsou patrné části pletence nebo blíže neidentifikovatelné detaily.

\footnotetext{
7 Rozměry dalších fragmentů $(\mathrm{v} \times \check{\text { s }} / \mathrm{cm}):$ č. $2: 7 \times 9,5 ;$ č. $3: 4,5 \times 8,4 ;$ č. $4: 5,6 \times 9 ;$ č. $5: 4 \times 9,6 ;$ č. $6: 3,2 \times 9,8 ;$ č. $7: 2,4 \times 6,8 ;$ č. $8: 2,8 \times 6$; č. $9: 2,5 \times 5,5 ;$ č. $10: 9 \times 8,7 ;$ osm drobných fragmentů.

8 Pouze na fragmentu č. 6 je keprová vazba $1 / 2 \mathrm{~S}$.

9 Údaje o barvách odpovídají současné barevnosti, která může být vlivem dlouhodobého uložení v hrobovém kontextu odlišná od barevnosti původní.
} 


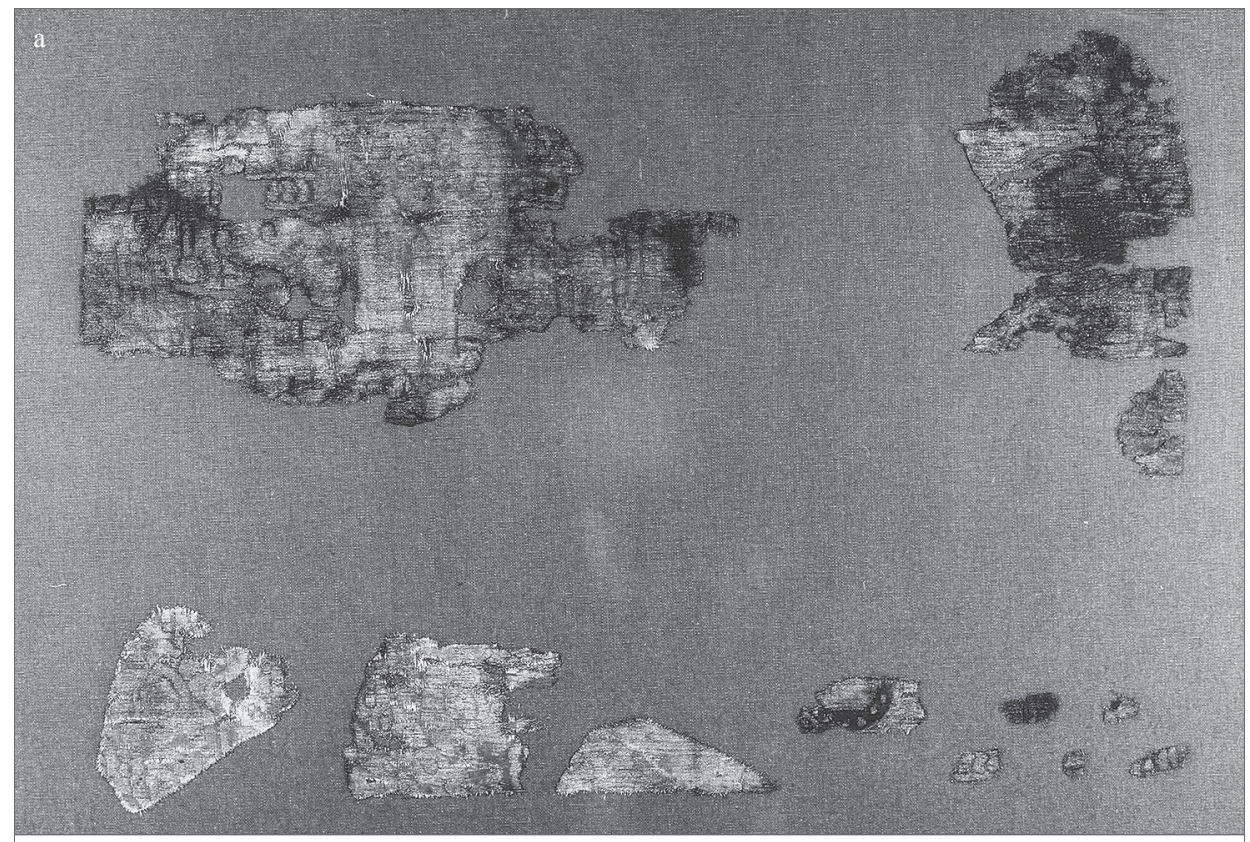

b

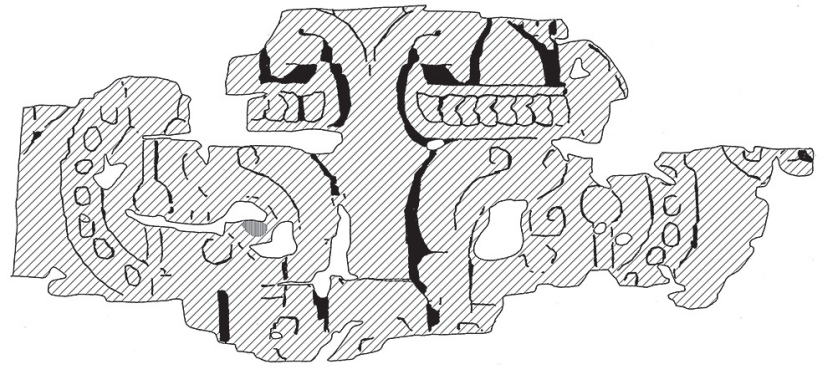

0 $10 \mathrm{~cm}$
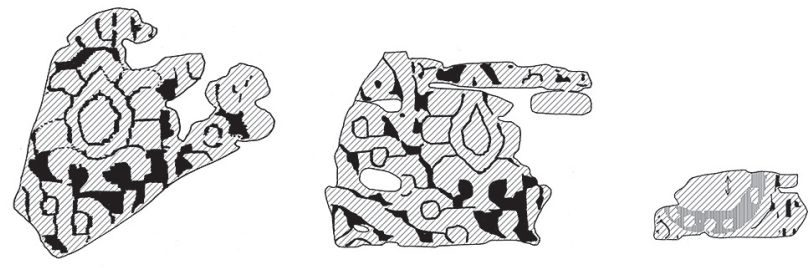

Obr. 3. Tkanina s pletencem, palmetami, perlovcem a zvíŕaty. a - adjustace fragmentů na panelu; b - části vzoru na fragmentech. () Správa Pražského hradu, foto J. Gloc, kresba V. Otavská.

Legenda k rekonstrukcím vzorů: bílá - základ; černá - efekt hedvábného lancé vzorujícího útku; horizontální šrafura - efekt liseré útku; šikmá šrafura - efekt kovového lancé vzorujícího útku; vertikální šrafura - efekt broché vzorujícího hedvábného útku; kř́žky - efekt kovového broché vzorujícího útku.

Abb. 3. Stoff mit Flechtkranz, Palmetten, Perlstab und Tieren. a - Montage der Fragmente auf einem Tableau; b - Teile des Musters auf den Fragmenten. (C) Verwaltung der Prager Burg, Foto J. Gloc, Zeichnung V. Otavská.

Legende für Musterrekonstruktionen: weiß - Grundgewebe; schwarz - Effekt eines Seiden-Lancé des musterbildenden Schussfadens; horizontale Schraffur - Liseré-Effekt des Schussfadens; schräg schraffiert - Effekt eines Metall-Lancé des musterbildenden Schussfadens; vertikal schraffiert - Broché-Effekt des musterbildenden Schussfadens aus Seide; Kreuze - Effekt eines Metall-Broché des musterbildenden Schussfadens. 
Celkem dobře čitelný detail vzoru je motiv palmet s pletencem, který by se dal interpretovat jako orámování (kruhového?) medailonu poměrně velkých rozměrů. Jedná se o starobylý prvek, vyskytující se např́iklad na hedvábných samitech s různobarevnými útky s motivem loveckých scén. Ohraničení medailonu je zde z vnější strany tvořeno pletencem, z vnitřní perlovcem, palmety jsou uprostřed. Látky jsou interpretovány jako byzantské se sasánovskými výtvarnými vlivy nebo syrské z první poloviny 9. století (např. Basilica di Sant’Ambrogio, Milán; Domschatzkammer, Kolín nad Rýnem; Museum August Kestner, Hannover; St. Calais, Sarthe; k tomu např. Muthesius 1997, 69-71). Takovéto samitum se nalézá i v chrámovém pokladu u sv. Víta jako součást vazby evangeliáře označovaného Cim. 2 (Metropolitní kapitula u sv. Víta, Praha; Bravermanová 2006, 199-200; Kubínová 2018).

I další látky, na nichž se vyskytuje obdobný motiv, a to pletenec z obou stran lemovaný perlovcem, většinou vytvářející orámování medailonů, jsou interpretovány jako poměrně starobylé, například samitum, z něhož jsou střiženy ozdobné lemy okolo průkrčníku a ramen na pohřební dalmatice papeže Klementa II. († 1047), je určeno jako byzantské ze začátku 11. století (Diözesanmuseum, Bamberk; Müller-Christensen 1960, 41-44, obr. 27-30). Orámování medailonů mohlo být vytvořeno též palmetami z vnitřní i vnější strany ohraničenými perlovcem, jako např́íklad na samitu s gryfy z dalmatiky interpretovaném jako syrské z 11. století (Eglise de Valère, Sion; Schmedding 1978, 250-251).

Dalším rozeznatelným prvkem vzoru je perlovec vytkaný broché efektem, který tvoří obvod malého kruhového medailonu, pravděpodobně umístěného mezi velké medailony. Takový motiv, provedený rovněž broché efektem, lze nalézt např́klad na lampasu z relikviářového souboru sv. Siviarda, určeného jako irácký z konce 12. století (Cathédrale Saint-Étienne, Sens; Wilckens 1991, 71, obr. 72).

Nejproblematičtější je interpretace posledního dochovaného výzdobného detailu látky z tumby sv. Václava. Lze jej možná určit jako dvojici k sobě obrácených zvířat s postroji, nejpravděpodobněji šlo o slony. Ti jsou např́íklad na samitu z relikviářového souboru ze Saint Josse-sur-Mer, sloni jsou však umístěni v obdélných polích. Látka je interpretována jako východoperská z doby po polovině 10. století (Musée du Louvre, Paříž; Wilckens 1991, 48, obr. 43). Proti sobě stojící sloni jsou i na výše zmíněném samitu z pohřební dalmatiky papeže Klementa II. (Müller-Christensen 1960, 41-44, obr. 27-30). Dvojice slonů umístěná v medailonu orámovaném na vnější straně pletencem, na vnitřní straně perlovcem a uvnitř rovněž s pletencem se nachází na tkanině určené jako východoíránská z 10. století (Musée d'Art religieux et d'Art mosan; Falke 1921, obr. 115).

V inventáŕi svatovítské katedrály se ještě v roce 1387 nacházela látka se „,slony“, ${ }^{10}$ která zřjejmě byla staršího původu.

Na základě rozboru vazební techniky a vzorových analogií lze tkaninu s pletencem, palmetami, perlovcem a zvířaty určit jako předovýchodní z 11.-12. století.

Dnes již nelze zjistit, jak se tato látka dostala do baziliky sv. Víta. Jednou z možností by např́klad mohla být cesta z roku 1147, kdy se král Vladislav II. vrátil z Uher, odkud si měl přivézt „přemnohá a skvostná roucha“11 a obdarovat jimi pražský kostel.

Na látce se zachovaly stopy po krejčovském zpracování, původní střih a použití tkaniny však nelze určit. Na dvou fragmentech (č. 1, 18) jsou vpichy po jehle, na třetím (č. 2) též vpichy a stopy po založení. Čtyři fragmenty (č. $1,3,4,5)$ mají rovně ve směru osnovy zastřižený kraj nebo kraj vzniklý roztržením či rozlomením v založení.

Je zřejmé, že této látky, která byla charakterizována jako „malý kousek látky červené se žlutým (...) vzorem, v němž se vyskytuje motiv pletencový (...)“, si A. Podlaha při otevření tumby $\mathrm{v}$ roce 1911 všiml $(1911,33)$.

10 „(...) cum elephantibus (...)“(Podlaha-Šittler 1903, inventář z roku 1387, zápis č. 296).

11 „(...) plurimis palliis preciosissimis (...)“(Letopis Vincencia, kanovníka Kostela pražského, 458). 


\subsection{Tkanina s nakoso vepsanými čtverci a hvězdicemi (obr. 4)}

Zachovala se ve čtrnácti fragmentech, z nichž největší (č. 2) má výšku $27,4 \mathrm{~cm}$ a šířku $23 \mathrm{~cm} .{ }^{12}$ Tkanina je hedvábný lampas. V základu provazuje hlavní osnova se základním útkem v keprové vazbě $2 / 1 \mathrm{~S}$. Vzor je vytkán dvěma efekty, tvořenými vzorujícími lancé útky I., II, které s vaznou osnovou béžové barvy provazují v plátnové vazbě. Vzorující útek II. provazuje v pásech (interrompu).

Obdobná technika se vyskytuje například na tkanině s kř́ižovo-hvězdicovým motivem pocházející z Předního východu nebo Španělska ze 14. století. Lancé vzorující útek je zde jen jeden (Abegg-Stiftung, Riggisberg; Otavský-Salím 1995, 224-225). Lampasy s geometrickým motivem s kufickými nápisy španělského nebo severoafrického původu z 14.-15. století mají v základu keprovou vazbu $1 / 3 \mathrm{~S}$ a ve vzoru plátnovou vazbu, jejich čtyři vzorující interrompu útky provazují přerušovaně v pásech (Abegg-Stiftung, Riggisberg; Otavský-Salím 1995, 236-239).

Vzor tkaniny s nakoso vepsanými čtverci a hvězdicemi tvoří na červenohnědém pozadí dva motivy. Prvním jsou dva do sebe nakoso vepsané čtverce (fragmenty č. 2, 3, 7), druhým motivem jsou hvězdice nebo stylizované květiny o šestnácti cípech či okvětních lístcích, v jejichž středu je rozeta (fragmenty č. 1, 2, 7, 8). Oba motivy tvořené efektem vzorujícího útku I. béžové barvy byly seskupeny do řad posunutých o polovinu raportu (fragmenty č. 2, 7). Vzájemně jsou podélně i příčně propojeny protáhlými šestiúhelníky vyplněnými perlovcem, vytvořeným efektem vzorujícího útku II. zelenobéžové barvy. Rekonstruovatelný raport vzoru je na výšku 19,6 cm a na šiřku 18,4 cm, avšak nelze vyloučit, že se jedná jen o určitý horizontální pás, na nějž navazoval pás s jiným vzorem.

Motiv nakoso vepsaných čtverců se nachází např́iklad na hedvábném lampasu čapky pocházející z Předního východu z př̀lomu 11. a 12. století (Victora and Albert Museum, Londýn; Wilckens 1991, 66, obr. 66), nebo na látce kasule a štoly zvané svatováclavské, interpretované jako lampas z druhé poloviny 13. století až první poloviny 14. století zhotovený na Předním východě, v Egyptě nebo islámské části Španělska (Metropolitní kapitula u sv. Víta, Praha;

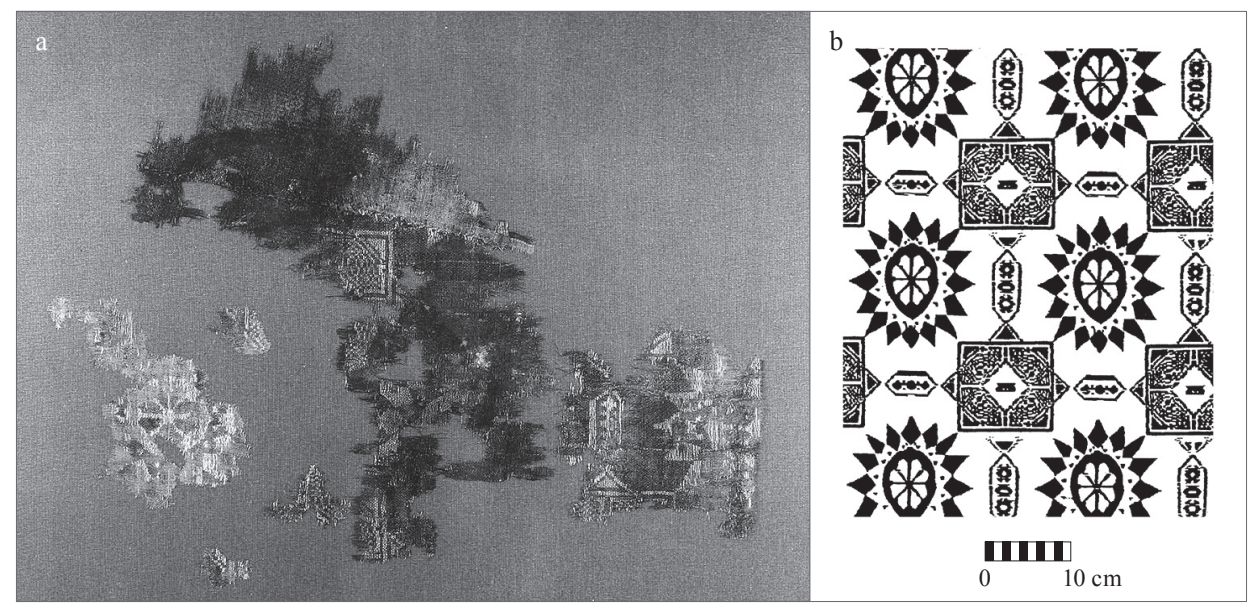

Obr. 4. Tkanina s nakoso vepsanými čtverci a hvězdicemi. a - adjustace fragmentů na panelu; b - rekonstrukce vzoru. (C) Správa Pražského hradu, foto J. Gloc, kresba V. Otavská.

Abb. 4. Stoff mit quer einbeschriebenen Quadraten und mit Sternen. a - Montage der Fragmente auf einem Tableau; $b$ - Rekonstruktion des Musters. (C) Verwaltung der Prager Burg, Foto J. Gloc, Zeichnung V. Otavská.

12 Rozměry dalších fragmentů $(\mathrm{v} \times \check{\text { s }} / \mathrm{cm})$ : č. $1: 26,8 \times 4 ;$ č. $3: 11,6 \times 26,8 ;$ č. $4: 11,7 \times 15 ;$ č. $5: 3,6 \times 2,6$ cm; č. $6: 2,2 \times 2,6 ;$ č. $7: 14,8 \times 15,8$; č. $8: 8,8 \times 4 ;$ č. $9: 5,8 \times 3,8 ;$ č. $10: 4 \times 3 ;$ č. $11: 4,4 \times 5$ cm; tř̆i nepatrné fragmenty. 
Bravermanová 2012). Motiv hvězdice je např́iklad na hedvábném samitu španělské provenience ze 13. století (Kunstgewerbemuseum, Berlin; Wilckens 1992, 77). Vzor ze dvou propojených geometrických motivů čtyřlistů a nakoso vepsaných čtverců, posunutých navzájem o polovinu raportu, je např́klad na lampasu španělského původu, datovaném do poloviny 13. století, z pohřebního pláště syna Alfonse X. (Santa Maria la Real de Huelgas, Burgos; Yarza Luaces 2005, 175). Obdobné vzory poskládané z různých tvarů se také nacházejí na výše zmíněných lampasech ze 14.-15. století - s křížovo-hvězdicovým motivem, se sítovým ornamentem a s geometrickým vzorem a kufickým nápisem (Otavský-Salím 1995, 224-225, 235-239).

Paramenta ušitá z tkanin, na nichž byl vytkán motiv hvězd, se ve svatovítském chrámu nacházela, i když podle četnosti zápisů spíše ojediněle. Vedle rostlinných motivů jsou hvězdy vkomponovány i mezi další geometrické prvky, např́íklad kruhy. ${ }^{13}$

Na základě rozboru vazební techniky a vzorových analogií lze tkaninu s nakoso vepsanými čtverci a hvězdicemi z tumby sv. Václava datovat do 13.-14. století, provenienčně ji lze přiřadit na Přední východ, do Egypta nebo do islámské části Španělska.

Na tkanině se zachovaly stopy po krejčovském zpracování, původní tvar tkaniny však nelze určit. Tři fragmenty (č. 1, 2, 3) jsou spolu sešity spojovacím zapošívacím stehem šicí nití: hedvábí, skaný zákrut $\mathrm{S} / 2 \mathrm{z}$, béžová barva.

\subsection{Tkanina se zašpičatělými ovály a arabským nápisem (obr. 5)}

Zachovala se ve dvaceti fragmentech, z nichž největší (č. 5) má výšku $8 \mathrm{~cm}$ a šířku $10,5 \mathrm{~cm} \cdot{ }^{14}$ Tkanina je hedvábný lampas. V základu je atlasová vazba 4/1 (décochement 3) tvořená hlavní osnovou a základním útkem. Vzor je tvořen jedním vzorujícím lancé útkem, který s vaznou osnovou provazuje v plátnové vazbě. Vazná osnova provazuje v základu i ve vzoru v plátnové vazbě par passée.

Vazebně odpovídající je například lampas se vzorujícím kovovým útkem s motivem dvojic zajíců v zašpičatělých oválech, který je zasazen do Egypta nebo Sýrie ze 14. století (Abegg-Stiftung, Riggisberg; Otavský-Salím 1995, 214-217). Uvést lze také shodně interpretovaný

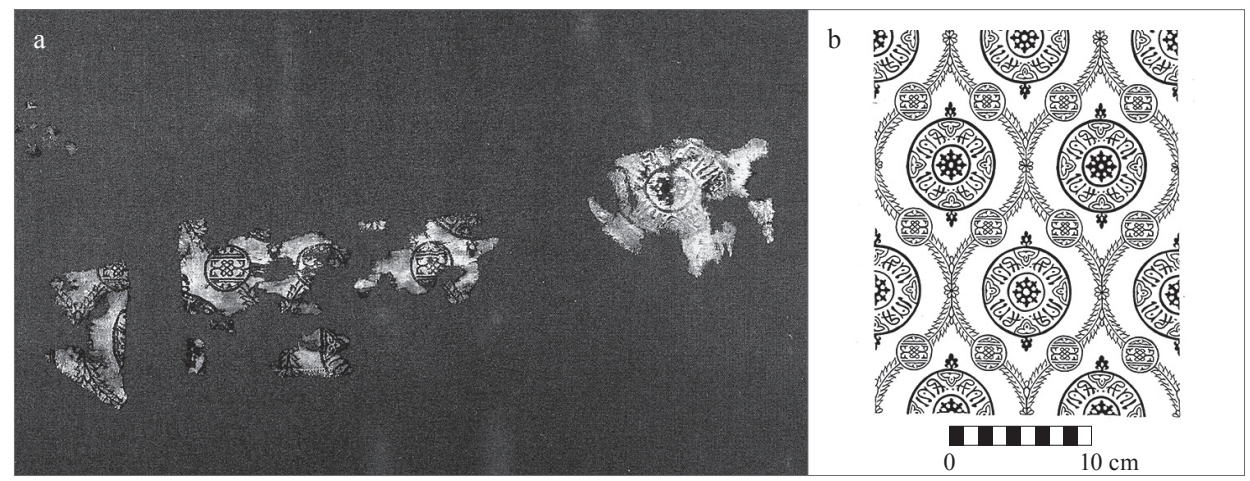

Obr. 5. Tkanina se zašpičatělými ovály a arabským nápisem. a - adjustace fragmentů na panelu, pohled na rub; b - rekonstrukce vzoru. (C) Správa Pražského hradu, foto J. Gloc, kresba V. Otavská.

Abb. 5. Stoff mit zugespitzten Ovalen und arabischer Inschrift. a - Montage der Fragmente auf einem Tableau, Ansicht der Rückseite; b - Rekonstruktion des Musters. (C) Verwaltung der Prager Burg, Foto J. Gloc, Zeichnung V. Otavská.

13, „(...) cum rosis et stellis auro (...)“(Podlaha-Šittler 1903, inventář z roku 1355, zápis č. 262); ,(...) habente rotas aureas et extra rotas stellas et rosas albas (...)“(Podlaha-Šittler 1903, inventář z roku 1387, zápis č. 462).

14 Rozměry dalších fragmentů $(\mathrm{v} \times \check{\mathrm{s}} / \mathrm{cm}):$ č. $1: 5,5 \times 8,5 ;$ č. $2: 2,5 \times 5 ;$ č. $3: 6,2 \times 9 ;$ č. $4: 9 \times 5 ;$ č. $6: 2,6 \times 2,1 ;$ č. $7: 1 \times 2,7 ;$ č. $8: 2,6 \times 0,9$; č. $9: 2,4 \times 1,6 ;$ č. $10: 1,6 \times 1,6 ;$ č. $11: 1,8 \times 1,5 ;$ č. $12: 1 \times 1,7 ;$ osm nepatrných fragmentů. 
lampas s dvojicemi ptáků mezi kruhy se zatočenou páskou (Kunstgewerbemuseum, Berlin; Wilckens 1992, 56).

Vzor tkaniny se zašpičatělými ovály a arabským nápisem je na zelenomodrém pozadí, je tvořen efektem žlutobílého vzorujícího útku, jímž je vytkána sít' zašpičatělých oválů z vavřínových listů, které jsou přerušované drobnými rozetami a kruhovými medailony s motivem nekonečného uzlu. Uvnitř oválů jsou kruhové terče, v jejichž středu je osmilistá rozeta, okolo níž je arabský nápis. ${ }^{15}$ Raport vzoru je 22,6 cm na výšku a 13,6 cm na šířku.

Kompozice vzoru je obdobná jako na výše zmíněném lampasu s motivem dvojic zajíců v zašpičatělých oválech (Otavský-Salím 1995, 214-217). Kompozice, a navíc i shodný arabský nápis uvnitř oválů, se opět nachází na tkanině se zašpičatělými ovály a lotosy, zasazené do Egypta nebo Sýrie ze 14. století. Látka je lampas, v základu je keprová vazba 4/1 S, ve vzoru pak keprová vazba 1/2 S (Kunstgewerbemuseum, Berlin; Wilckens 1992, 60).

Jak dokládají inventáře svatovítské katedrály, paramenta z látek, na nichž byla též vytkaná písmena, někdy charakterizovaná jako „pohanská“ ${ }^{16}$ tvořila poměrně časté vybavení chrámu.

Na základě rozboru vazební techniky a vzorových analogií lze tkaninu se zašpičatělými ovály a arabským nápisem určit jako syrskou nebo egyptskou ze 14. století.

Na tkanině se zašpičatělými ovály a arabským nápisem se zachovaly stopy po krejčovském zpracování, původní střih a použití tkaniny však nelze určit. Na šesti fragmentech (č. 1, 2, 3, 4, $5,8)$ jsou stopy založení, vpichy po jehle s drobnými zbytky šicí nitě modré barvy z pravděpodobně rostlinného materiálu.

\subsection{Tkanina s podélnými pruhy s palmetami, rozetami a srdčitými motivy (obr. 6)}

Zachovala se ve čtyřech fragmentech, z nichž největší (č. 1) má výšku $12,5 \mathrm{~cm}$ a šiřku $31,8 \mathrm{~cm} .{ }^{17}$ Tkanina je hedvábný lampas. V základu je atlasová vazba 4/1 (décochement 3) tvořená hlavní osnovou dvojí barvy a základním liseré útkem. Vzor je tvořen dvěma efekty. Prvním je efekt základního liseré útku, který je vázán v plátnové vazbě vaznou osnovou, druhým je efekt vzorujícího kovového lancé útku, který provazuje s vaznou osnovou v plátnové vazbě. Vazná osnova provazuje v základu i v obou efektech vzoru v plátnové vazbě par passée.

Shodná vazební technika se nachází na lampasu tzv. štoly sv. Himeria, který je určen jako turkestánský ze 14. století (Kloster, Mariastein; Schmedding 1978, 149-151). Obdobná technika se nachází například na tkanině (č. II) dalmatiky se vzorem vyklánějících se lotosových květů a drobných květů. V základu je atlasová vazba 4/1 (décochement 3), vzor tvoří efekt základního liseré útku vázaného vaznou osnovou v plátnové vazbě a dva vzorující lancé útky - jeden z pozlaceného proužku živočišného podkladu, druhý hedvábný. Oba lancé útky provazují s vaznou osnovou v plátnové vazbě. Látka je určena jako středoasijská nebo ze severní Číny z první poloviny 14. století (Kulturhistorisches Museum der Hansestadt Stralsund, Stralsund; Fircks 2008, 72-91). Shodná technika se také nachází na tkanině se zašpičatělými ovály z pásek s arabským písmem z druhé poloviny 14. století, vzhledem k provedení kovového útku je její provenience určena jako předovýchodní (Sbírky Pražského hradu, Praha; Bravermanová 2016, 108).

Tkanina s podélnými pruhy s palmetami, rozetami a srdčitými motivy má stř́ídavě béžové a béžovozelené pruhy. ${ }^{18}$ Béžovozelené jsou vyplněné srdčitými motivy, lemované linkami, obojí vytvořené vzorujícím kovovým útkem. V béžových pruzích se nacházejí bud' střídavě vykloněné palmety, nebo rozety s palmetami. Tyto dva motivy jsou provedené částečně liseré útkem a částečně vzorujícím kovovým útkem. Výška raportu vzoru se nezachovala, šířka je 13,5-14,5 cm.

15 Nápis byl přeložen jako „sultán“ (nápis přečetla a přeložila J. Štěpková z NM Praha; Státní restaurátorské ateliéry 1985).

16 ,....) literis aureis (...)“ (Podlaha-Šittler 1903, inventáŕ z roku 1355, zápis č. 247); „(...) et literas gentilium (...)“ (Podlaha-Šittler 1903, inventář z roku 1387, zápis č. 432).

17 Rozměry dalších fragmentů $(\mathrm{v} \times \check{\mathrm{s}} / \mathrm{cm}):$ č. $2: 12 \times 3$; dva nepatrné fragmenty.

18 Barva hlavních osnov se střídá po různě širokých úsecích: $8,2 \mathrm{~cm}$ béžová; $5,3 \mathrm{~cm}$ béžovozelená; $8,4 \mathrm{~cm}$ béžová; $5,7 \mathrm{~cm}$ béžovozelená. 
Vzor komponovaný do podélných pruhů se nachází též na výše zmíněném lampasu tzv. štoly sv. Himeria. V pruzích tvořených různobarevnými osnovami jsou stř́idavě umístěny lotosové květy a geometrické obrazce (Schmedding 1978,149-151). Obdobný vzor, pouze s jiným motivem v oddělujících pásech, se též nachází na lampasu jedné z pohřebních textilií bamberského dómu. Je interpretován jako středoasijský ze 13. století (Diözesanmuseum, Bamberk; Helmecke 2001, 22-23, 67). Obdobně využité různobarevné osnovy se nachází i na středoasijské nebo severočínské tkanině s podélnými pruhy a zlatým vzorem z konce 13. až první poloviny 14. století (Sbírky Pražského hradu, Praha; Bravermanová a kol. 2017, 31-34).

V inventáři svatovítského chrámu byly vzory látek, které zdobily motivy komponované do podélných pruhů, charakterizované jako „na způsob štol“. Pokud v podélných pruzích byly

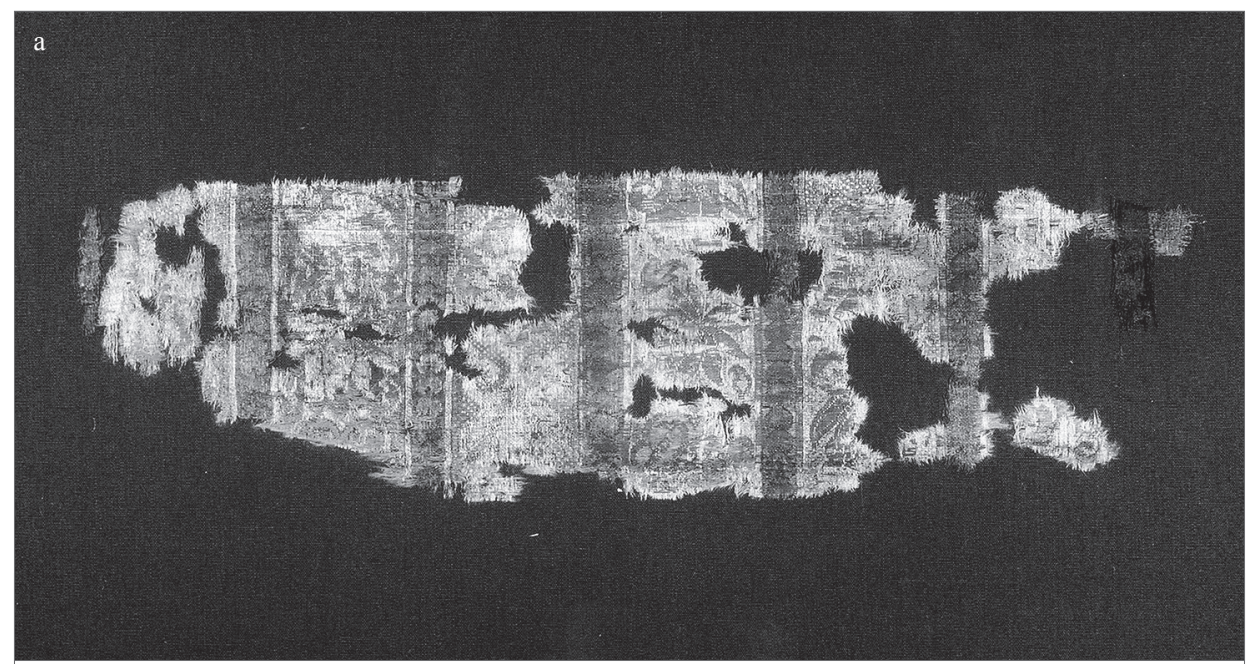

b

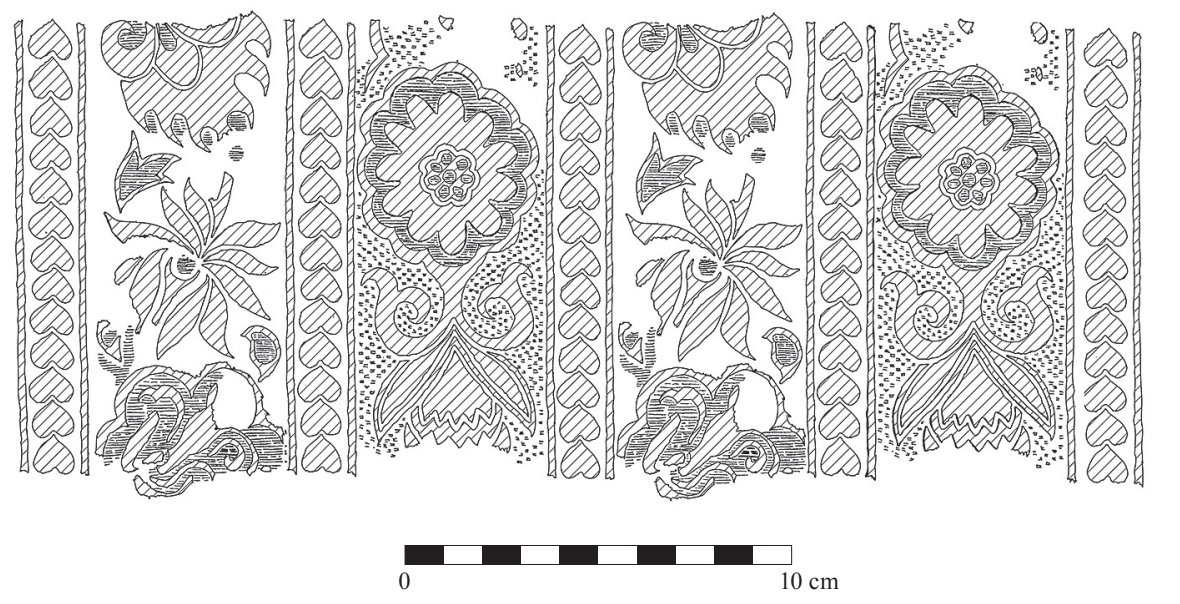

Obr. 6. Tkanina s podélnými pruhy s palmetami, rozetami a srdčitými motivy. a-adjustace fragmentů na panelu, pohled na rub; b - rekonstrukce vzoru. (C) Správa Pražského hradu, foto J. Gloc, kresba V. Otavská.

Abb. 6. Stoff mit Längsstreifen und Palmetten, Rosetten sowie mit herzförmigen Motiven. a - Montage der Fragmente auf einem Tableau, Ansicht der Rückseite; b - Rekonstruktion des Musters. (C) Verwaltung der Prager Bukrg, Foto J. Gloc, Zeichnung V. Otavská. 
rostlinné motivy, byly popsány např́klad jako „mající růže $v$ podélných pruzich a ve středu velké zlaté listy podobajicí se růžim". ${ }^{19}$

$\mathrm{Na}$ základě rozboru vazební techniky a vzorových analogií lze tkaninu s podélnými pruhy s palmetami, rozetami a srdčitými motivy určit jako středoasijskou, př́ipadně ze severní Číny z první poloviny 14. století.

$\mathrm{Na}$ látce se žádné krejčovské stopy nezachovaly, původní tvar ani funkci tkaniny tedy nelze určit.

Je zřejmé, že tuto látku, charakterizovanou jako „tmavozelená se žlutým vzorem (...): úzké pruhy oddělené od sebe ornamentem složeným z řady srdcovitých lupénků, v pruzich stř́laji se dva různé ornamenty rostlinné", A. Podlaha při otevření tumby v roce 1911 zaregistroval $(1911,33)$.

\subsection{Tkanina s kopinatými listy a medailony (obr. 7)}

Zachovala se ve dvou fragmentech o rozměrech: č. 1 - výška 26,3 cm a šířka 13,5 cm a č. 2 - výška $25,6 \mathrm{~cm}$, šířka $14 \mathrm{~cm}$. Tkanina je hedvábný lampas. V základu je keprová vazba $3 / 1 \mathrm{~S}$ z hlavní osnovy a základního útku. Vzor je tvořen dvěma efekty - efektem vzorujícího lancé útku I. a efektem vzorujícího kovového lancé útku II., které $\mathrm{s}$ vaznou osnovou provazují $\mathrm{v}$ plátnové vazbě. Vazná osnova provazuje v základu i ve vzoru v plátnové vazbě par passée.

Velmi obdobná vazební technika se nachází na látce $\mathrm{s}$ rostlinným vzorem, $\mathrm{z}$ níž byl ušit manipul. V základu je keprová vazba 3/1 S, vzor je tvořen dvěma efekty - efektem vzorujícího lancé hedvábného útku (latté, interrompu) a efektem vzorujícího lancé útku na jedné straně pozlaceného, na druhé straně postř́ibřeného proužku živočišného podkladu. Vzorující útky jsou vázány na líci tkaniny vaznou osnovou v plátnové vazbě. Tkanina je interpretována jako středoasijská z první poloviny 14. století (Kulturhistorisches Museum der Hansestadt Stralsund, Stralsund; Fircks 2008, 92-95). Srovnatelná je i technika jednoho lampasu z pohřebních textilií bamberského dómu.

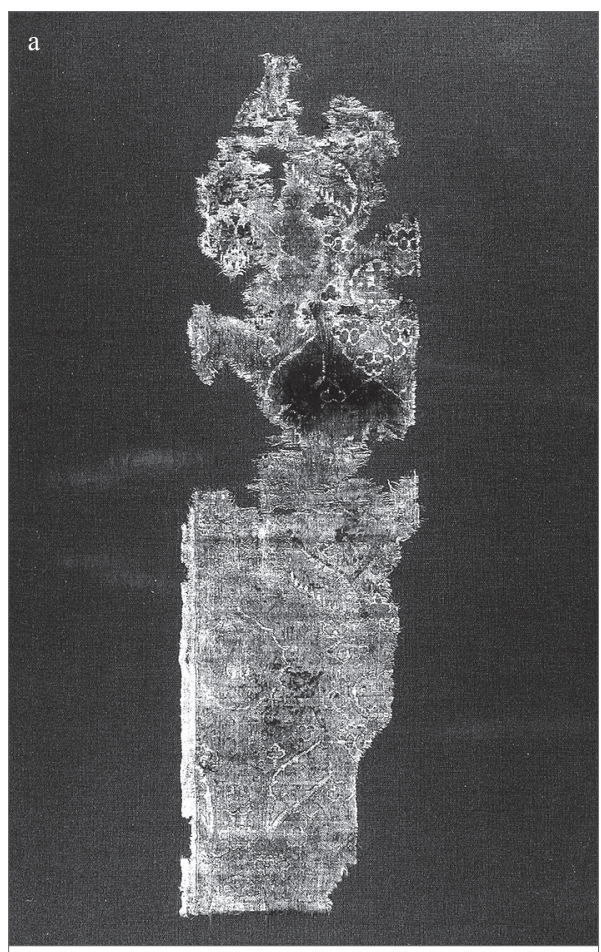

b

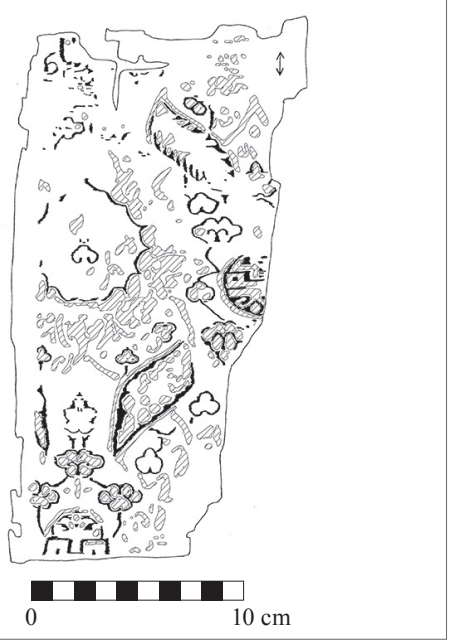

Obr. 7. Tkanina s kopinatými listy a medailony. a - adjustace fragmentů na panelu; $b$ - části vzoru na fragmentu. (C) Správa Pražského hradu, foto J. Gloc, kresba V. Otavská.

Abb. 7. Stoff mit lanzettenförmigen Blättern und Medaillons. a - Montage der Fragmente auf einem Tableau; b Teile des Musters auf einem Fragment. (C) Verwaltung der Prager Burg, Foto J. Gloc, Zeichnung V. Otavská.

19 „(...) ad modum stolarum (...)“ (Podlaha-Šittler 1903, inventář z roku 1368, zápis za č. 243 inventáře z roku 1355; Podlaha-Šittler 1903, inventár z roku 1387, zápisy č. 236, 237, 338, 342, 371, 431, 433, 445); „(...) habens rosas ad modum stolae et in medio magnotum foliorum de auro similiter rosas (...)“ (Podlaha-Šittler 1903, inventář z roku 1387, zápis č. 384). 
V základu je keprová vazba 3/1 S, vzor je tvořen dvěma efekty - efektem prvního vzorujícího lancé hedvábného útku a efektem druhého vzorujícího lancé útku zhotoveného z pozlaceného proužku živočišného podkladu obtočeného kolem bavlněné duše. Vzorující útky jsou vázány na líci tkaniny vaznou osnovou v plátnové vazbě. Tkanina je interpretována jako středoasijská ze 13.-15. století (Diözesanmuseum, Bamberk; Helmecke 2001, 48,70).

Pozadí vzoru tkaniny s kopinatými listy a medailony je zelenošedé, zlatý a béžovošedý vzor je uspořádaný do řad vzájemně posunutých o polovinu raportu. Střídají se dva motivy, jednak dvojice kopinatých listů, nad nimiž je kruhový medailon s motivem částečně připomínajícím stylizovaný čínský znak dlouhého života obklopený propojenými obláčky, a dále lotosový květ. Větší část vzoru je provedena vzorujícím kovovým útkem II., vzorující útek I. vytváří pouze kontury jednotlivých prvků. Raport vzoru je na výšku $24,2 \mathrm{~cm}$ a na šířku zhruba $8,5 \mathrm{~cm}$.

Některé prvky tohoto vzoru, především kopinaté lístky a malé medailony vyplněné rostlinným ornamentem, se nacházejí na bohatě kovovým útkem (pozlacený proužek živočišného podkladu obtočený kolem hedvábné duše) vytkaném lampasu. Je interpretován jako perský nebo ze západní části Střední Asie z konce 13. a první poloviny 14. století (Abegg-Stiftung, Riggisberg; OtavskýWardwell 2011, 250-251). Obdobné prvky - místo medailonů jsou lotosové květy - se nacházejí i na lampasu s palmetami, úponky a lístky. Látka má trochu jiné technologické parametry - základní útek je bavlněný a kovová nit je zhotovena z pokoveného proužku živočišného podkladu obtočeného kolem bavlněné duše. Tkanina je interpretována jako irácká (Kunstgewerbemuseum, Berlin; Wilckens 1992, 45-46) nebo středoasijská (Wardwell 1988-1989, 105-106) z první poloviny 14. století. Motiv stylizovaného znaku dlouhého života je typickým čínským prvkem, na textiliích se uplatňoval hojně od 14. století (Zhao Feng 1999, 252-253).

Látky zdobené převážně rostlinnými motivy, charakterizované jako panni tartarici, baldakiny nebo nasseti, neboli tkaniny asijského původu (k tomu např. Bravermanová-Březinová 2016, 116), byly ve svatovítských inventáŕích popisovány např́iklad jako „,s květinami“, „s malými listky“", ,s rüžemi““ či ,s liliemi““. ${ }^{20}$

Na základě rozboru vazební techniky a vzorových analogií lze tkaninu s kopinatými listy a medailony určit jako výrobek ze Střední Asie nebo severní Číny z první poloviny 14. století. Byl zde použit útek z pozlaceného proužku živočišného podkladu, což je typické pro Střední Asii.

Na fragmentech nejsou žádné stopy po krejčovském zpracování, původní tvar tkaniny tak nelze určit. Podle nálezových okolností se zřejmě jedná o pozůstatek látky, která měla zvnějšku pokrývat gotickou schránu nalezenou ve vnitřním prostoru oltáře (Podlaha 1911, 30, obr. 5).

\subsection{Tkanina s makovicemi, kachnami a lvy (obr. 8)}

Zachovala se ve dvou fragmentech o rozměrech: č. 1 - výška $20 \mathrm{~cm}$, šiřka $13 \mathrm{~cm}$ a č. 2 výška 11,7 cm, šířka 28,7 cm. Tkanina je hedvábný lampas (dutinná tkanina v základu; lampas à fond double étoffe). $\mathrm{V}$ základu je keprová vazba $2 / 1 \mathrm{~S}$ vázaná hlavní osnovou a základním útkem, pod tím je oddělená vrstva $\mathrm{v}$ keprové vazbě $1 / 2 \mathrm{~S}$ tvořená vaznou osnovou a vzorujícími lancé útky I., II. Vzor je tvořen třemi efekty - první dva jsou efekty I. nebo II. vzorujícího lancé útku, které provazují v keprové vazbě $1 / 2 \mathrm{~S}$ v pásech (interrompu). Třetím je efekt vzorujícího kovového broché útku, který provazuje s vaznou osnovou v keprové vazbě $1 / 2 \mathrm{~S}$. Vazná osnova prochází pod základním útkem a na rubu provazuje právě nevzorující útek/útky I., II.

Shodná vazební technika se nachází např́íklad na lampasu se skákajícími lvy a ptáky, interpretovaném jako italský z poslední třetiny 14. století až začátku 15. století (Abegg-Stiftung, Riggisberg; Otavský-Wardwell 2011, 278-280). Táž technika je i na lampasu s podloubím, listovými růžicemi a malými zvířaty a rostlinami. Tkanina je i shodně interpretována (Abegg-Stiftung, Riggisberg; Otavský-Wardwell 2011, 278-280).

20 „,cum floribus“ (Podlaha-Šittler 1903, inventář z roku 1354, zápis č. 117); „cum minutis foliis“ (Podlaha-Šittler 1903, inventář z roku 1355, zápis č. 230); „cum rosis“ (Podlaha-Šittler 1903, inventáŕ z roku 1355, zápis č. 250); „,cum liliis“ (Podlaha-Šittler 1903, inventáŕ z roku 1387, zápis č. 375). 
Na okrovém pozadí tkaniny s makovicemi, kachnami a lvy je šedomodrý a zlatý vzor komponovaný v podélných řadách. $V$ jedné řadě je svazek makovic, po jejichž stranách jsou od sebe odvrácení ležící lvi, nad nimiž jsou zárící oblaka. Ve druhé řadě jsou dvě k sobě otočené kachny na vlnách, nad nimiž je trs oválných listů, po stranách je motiv granátového jablka. Velká část vzoru je vytvořena efektem vzorujícího útku I., pouze malé detaily efektem vzorujícího útku II. Řady jsou od sebe odděleny pásem, v němž byl vzorujícím broché kovovým útkem vytkán zř̀jmě drobný vzor, jehož detaily nejsou známé. Výška raportu vzoru se nezachovala, šířka je $11,7 \mathrm{~cm}$.

Obdobný vzor komponovaný $\mathrm{v}$ podélných řadách, kde $\mathrm{v}$ jednom pásu jsou kytice s palmetami, ve druhém rozetové květy a ve třetím větve s granátovými plody a labutěmi, se nachází na lampasu interpretovaném jako italský z doby okolo roku 1400 (Uměleckoprůmyslové museum, Praha; Zeminová 1987, 47-48, obr. 404). Shodně je komponovaný vzor lampasu pluviálu, v jednom pásu jsou lvi, kozy a rostlinný ornament, ve druhém pak králíci s trsy listů a granátová



$\mathrm{b}$
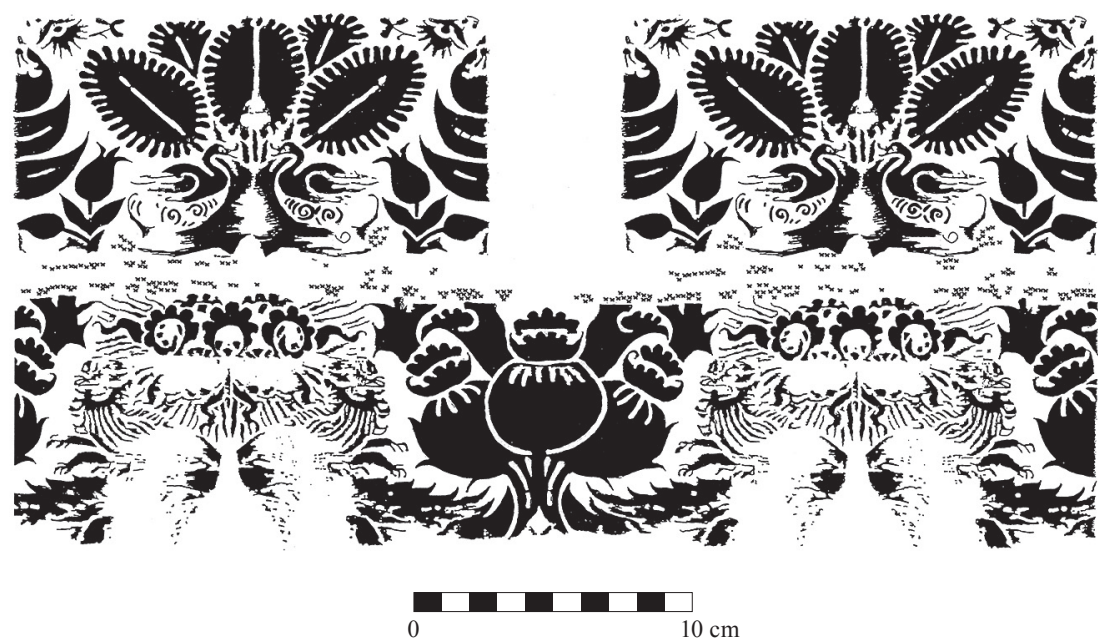

Obr. 8. Tkanina s makovicemi, kachnami a lvy. a - adjustace fragmentů na panelu; b-rekonstrukce vzoru. (C) Správa Pražského hradu, foto J. Gloc, kresba V. Otavská.

Abb. 8. Stoff mit Mohnköpfen, Enten und Löwen. a - Montage der Fragmente auf einem Tableau; b - Rekonstruktion des Musters. (C) Verwaltung der Prager Burg, Foto J. Gloc, Zeichnung V. Otavská. 
jablka. Látka je interpretována jako italská z poslední třetiny 14. století (Dom St. Peter und Paul, Brandenburg; Jehle-Wetter 2005, 164-169).

V inventářích svatovítského chrámu se látky, na nichž jsou vytkány společně rostlinné i zvířecí motivy, vyskytovaly poměrně často. Jsou charakterizovány například jako ,se psy, lvy a zdvojenými lístky“. Jednotlivé detaily mohly být uspořádány i do pásů, například „v pásech majici zelené kvèty a zlaté lvy".21

$\mathrm{Na}$ základě rozboru vazební techniky a vzorových analogií lze tkaninu s makovicemi, kachnami a lvy určit jako italskou z poslední třetiny 14. století až začátku 15. století.

Na tkanině se zachovaly stopy po krejčovském zpracování, původní střih a použití tkaniny však nelze určit. Vpichy po jehle a stopy po založení se zachovaly na obou fragmentech.

Je zřejmé, že i této látky, která byla charakterizována jako „látka hnědožlutá s tmavozeleným vzorem (...), v němž mimo rostlinné stylizované prvky spatřuji se symetricky proti sobě postavené drobné labutě, delfini ocasy spojeni aj.“, si A. Podlaha při otevření tumby v roce 1911 všiml $(1911,33)$.

\subsection{Tkanina s palmetami (obr. 9)}

Zachovala se ve 36 fragmentech, dva největší mají rozměry (výška $\times$ šírka) $21,4 \times 20 \mathrm{~cm}($ č. 1) a $21,5 \times 15,5 \mathrm{~cm}(\check{c} .2){ }^{22}$

Tkanina je hedvábný lampas. V základu je keprová vazba 2/1 S tvořená hlavní osnovou a základním útkem. Ve vzoru tvoří vzorující lancé útek s vaznou osnovou plátnovou vazbu. Vazná osnova provazuje v základu i ve vzoru v plátnové vazbě par passée.

Shodná vazební technika se nachází na lampasu s listy vinné révy umístěnými v zašpičatělých oválech. Tkanina je určena jako italská z druhé poloviny 14. století (Kunstgewerbemuseum, Berlin; Wilckens 1992, 122-123). Obdobná technika je také na lampasu se vzorem komponovaným do řad s leopardy, orly a slunečním motivem, určeném jako italský ze 14. století. Vzor je však vytkán dvěma hedvábnými lancé útky (Deutsches Textilmuseum, Krefeld; Tietzel 1984, 372-373).

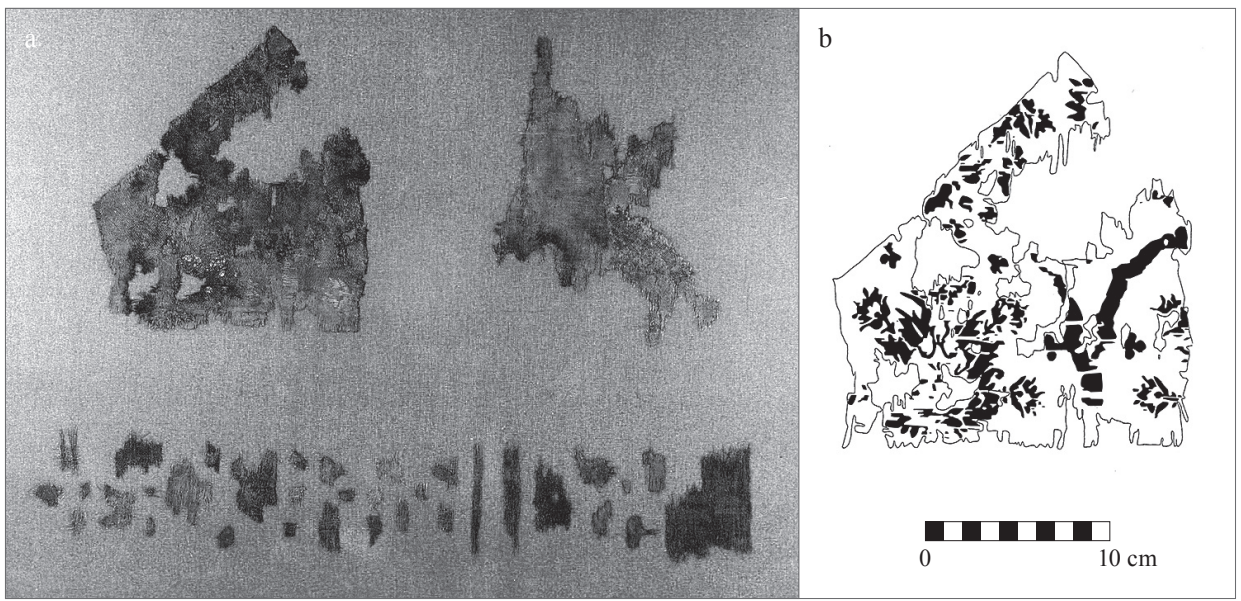

Obr. 9. Tkanina s palmetami. a - adjustace fragmentů na panelu; b - části vzoru na fragmentu. ( Správa Pražského hradu, foto J. Gloc, kresba V. Otavská.

Abb. 9. Stoff mit Palmetten. a - Montage der Fragmente auf einem Tableau; b - Teile des Musters auf einem Fragment. (C) Verwaltung der Prager Burg, Foto J. Gloc, Zeichnung V. Otavská.

21, „(...) cum canibus et leonibus et duplicibus foliis (...)“(Podlaha-Šittler 1903, inventář z roku 1387, zápis č. 373); „(...) ad modum stolarum, habens flores virides et leonculos de auro (...)“(Podlaha-Šittler 1903, inventář z roku 1387, zápis č. 435).

22 Rozměry dalších fragmentů $(\mathrm{v} \times \check{\mathrm{s}} / \mathrm{cm})$ : č. $3: 4,5 \times 5 ;$ č. $4: 3,5 \times 2,6 ;$ č. $5: 3,2 \times 2,5 ; 31$ nepatrných fragmentů. 
Kompletní vzor nelze vzhledem k fragmentárnosti tkaniny s palmetami určit, zachovaly se z něj jenom některé detaily. Na červenohnědém pozadí je béžový vzor palmet zakomponovaných do pravidelně se v řadách opakujících větších oválných motivů. Raport vzoru nelze určit.

Ovoce obklopené rozetou je např́íklad na damašku tkaniny kasule, dalmatiky a tunicelly vročeném do druhé čtvrtiny 15. století, původem z Itálie (Dom St. Peter und Paul, Brandenburg; Jehle-Wetter 2005, 234-245). Granátová jablka jsou na sametu určeném jako italský z druhé čtvrtiny 15. století (Dom St. Peter und Paul, Brandenburg; Jehle-Wetter 2005, 234-245). Arabeskový motiv z hvězd a roset umístěný $\mathrm{v}$ zašpičatělých oválech $\mathrm{z}$ malých rozet je zase na lampasu určeném jako španělský z 15. století (Kunstgewerbemuseum, Kolín nad Rýnem; Markowsky 1976, 136).

Skutečnost, že v 15. století se ve svatovítském chrámu nacházela paramenta ušitá z látek zdobených jenom květy, které byly vytkány barevnými, nikoliv však kovovými nitěmi, dosvědčují i některé zápisy v inventářích. ${ }^{23} \mathrm{Na}$ základě rozboru vazební techniky a vzorových analogií lze tkaninu s palmetami určit jako italskou nebo španělskou z 15. století.

Přestože se na jednom fragmentu (č. 2) tkaniny zachovaly stopy po založení s vpichy po jehle, její původní tvar a funkci nelze určit.

V popise A. Podlahy jsou zmíněny dvě obdobné látky $(1911,33)$. Jedna je charakterizována jako „látka červená se žlutým vzorem (...) granátového jablka“, druhá jako „látka tmavohnědá $s$ bohatým tmavozeleným vzorem (...), jenž jest rovněž variací vzoru granátového jablka“. Tyto popisy lze vztáhnout jak na tkaninu s palmetami, tak na tkaninu s palmetami a granátovými jablky (viz 4.8), avšak bez možnosti odlišení.

\subsection{Tkanina s palmetami a granátovými jablky (obr. 10)}

Zachovala se v osmi fragmentech, z nichž největší má výšku $38 \mathrm{~cm}$ a šířku $20 \mathrm{~cm}$ (sešité fragmenty č. 1 a 2). ${ }^{24}$ Tkanina je hedvábný lampas. V základu je keprová vazba $2 / 1 \mathrm{~S}$ tvořená hlavní osnovou

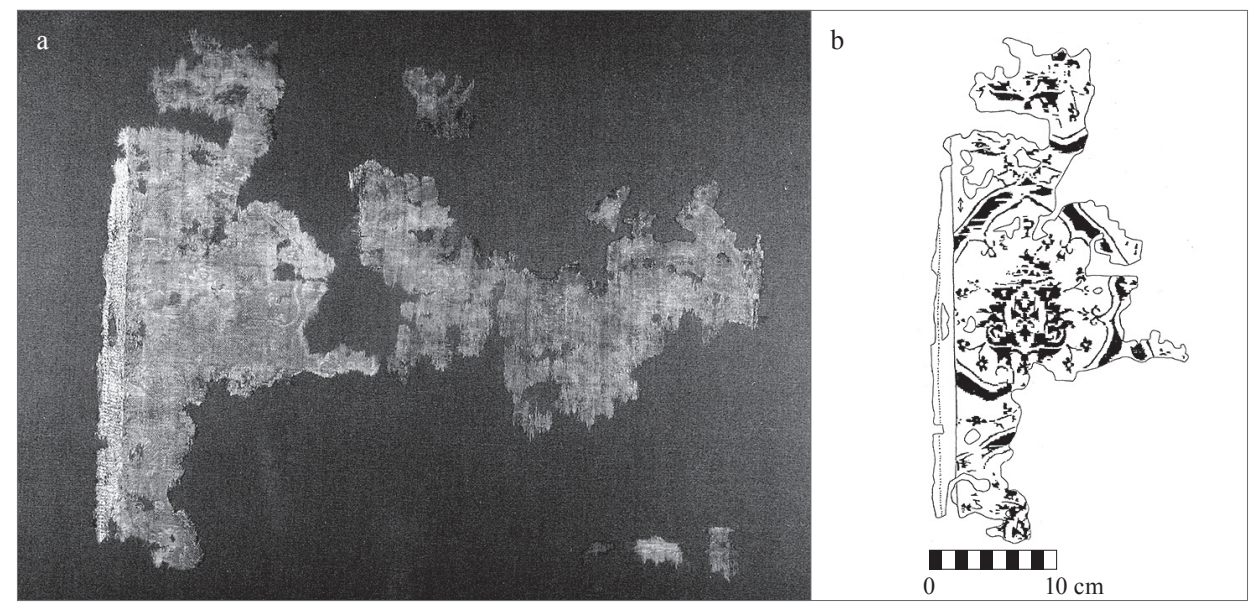

Obr. 10. Tkanina s palmetami a granátovými jablky. a - adjustace fragmentů na panelu; b - části vzoru na fragmentu. (C) Správa Pražského hradu, foto J. Gloc, kresba V. Otavská.

Abb. 10. Stoff mit Palmetten und Granatäpfeln. a - Montage der Fragmente auf einem Tableau; b - Teile des Musters auf einem Fragment. (C) Verwaltung der Prager Burg, Foto J. Gloc, Zeichnung V. Otavská.

23, „(...) rubea cum floribus de colore viridi sine auro (...)“ (Podlaha-Šittler 1903, inventáŕ z roku 1441, zápis č. 5).

24 Rozměry dalších fragmentů $(\mathrm{v} \times \check{\mathrm{s}} / \mathrm{cm}):$ č. $3: 15 \times 30,2$; pět nepatrných fragmentů. 
a základním útkem. Ve vzoru provazuje vzorující lancé útek s vaznou osnovou v plátnové vazbě. Vazná osnova provazuje v základu i ve vzoru v plátnové vazbě par passée.

Úplný vzor nelze vzhledem k fragmentárnosti tkaniny s palmetami a granátovými jablky určit, zachovaly se z něj jenom některé detaily. Na hnědočerveném pozadí je béžový vzor palmet zakomponovaných do pravidelně se v řadách opakujících granátových jablek (?). Raport vzoru nelze určit.

Tkanina s palmetami a granátovými jablky je vazebně i vzorem velmi podobná jako látka tkaniny s palmetami (viz 4.7), proto jako analogie vazební techniky i obdobu vzoru lze použít shodné prŕíklady u obou tkanin. Je možné ji tedy též určit jako italskou nebo španělskou z 15. století.

Na jednom fragmentu (č. 1) látky s palmetami a granátovými jablky jsou zachovány stopy po založení s vpichy po jehle, s jeho pevným okrajem je rovněž pevným okrajem sešit jiný fragment (č. 2). Přestože se tedy zachovaly stopy po krejčovském zpracování, původní tvar a funkci tkaniny nelze již dnes určit.

\subsection{Nevzorované tkaniny v plátnové vazbě}

Nevzorované hedvábné tkaniny v plátnové vazbě nevykazují žádné znaky, podle nichž by bylo možné je přesněji datovat či určit provenienci. Lze pouze konstatovat, že byly v průběhu středověku vyrobeny v některé z hedvábnických oblastí v Asii či Evropě.

\subsubsection{Růžovohnědá tkanina}

Hedvábná tkanina se zachovala v jednom fragmentu o rozměrech $39,3 \mathrm{~cm}$ na výšku a $31 \mathrm{~cm}$ na šírku.

Na tkanině se nezachovaly žádné stopy po krejčovském zpracování, její původní tvar a funkci tak nelze určit.

Ve zprávě A. Podlahy se hovoří o tom, že v podzemní olověné truhle se nalezly zbytky červeného a zhnědlého hedvábí. Vzhledem ke změnám barevnosti tkanin nelze určit, ke které ze zachovaných nevzorovaných látek lze popis vztáhnout (Podlaha 1911, 97).

\subsubsection{Hnědá tkanina}

Hedvábná tkanina se zachovala v deseti fragmentech, z nichž největší má výšku $30 \mathrm{~cm}$ a šiřrku $22 \mathrm{~cm}($ č. 1$){ }^{25}$

$\mathrm{Na}$ jednom fragmentu (č. 2) se dochovala šicí nit: rostlinný materiál, skaný zákrut $\mathrm{S} / 2 \mathrm{~s}$, modrá barva. Přestože se zachovaly stopy po krejčovském zpracování, původní tvar a funkci tkaniny nelze určit.

\subsubsection{Béžová tkanina}

Hedvábná tkanina se zachovala v sedmnácti fragmentech, z nichž největší má výšku i šířku 26 cm (fragm. č. 1$){ }^{26}$

Na jednom fragmentu (č. 1) se zachovala šicí nit: hedvábí, skaný zákrut Z/2s, béžová barva. Přestože se zachovaly stopy po krejčovském zpracování, původní tvar a funkci tkaniny nelze určit.

25 Rozměry dalších fragmentů $(\mathrm{v} \times \check{\mathrm{s}} / \mathrm{cm}):$ č. $2: 26 \times 18 ;$ č. $3: 18 \times 21 ; \check{c} .4: 1 \times 3 ;$ č. $5: 3 \times 10 ;$ č. $6: 4 \times 13 ;$ č. $7: 1,6 \times 7 ;$ č. $8: 2 \times 21 ; \check{c} .9: 1,6 \times 3,3$; č. 10: $3,3 \times 4$; mnoho nepatrných fragmentů.

26 Rozměry dalších fragmentů: č. $2: 8 \times 3 ;$ č. $3: 10 \times 10$; č. $4: 13 \times 12 ;$ č. $5: 4 \times 12 ;$ č. $6: 8 \times 8 ;$ č. $7: 8 \times 8 ;$ č. $8: 6 \times 6 ; 9$ fragmentů o rozměrech do cca $3 \times 3 \mathrm{~cm}$; mnoho nepatrných fragmentů. 


\subsubsection{Oranžovočervená tkanina}

Hedvábná tkanina se zachovala v šestnácti fragmentech, z nichž největší má výšku 13,4 cm a šířku $13 \mathrm{~cm}$ (č. 1$) \cdot{ }^{27}$

Na několika fragmentech (fragm č. 1, 2, 3, 8, 9, 12) se zachovalo původní zastřižení a dva druhy šicí nitě: a) rostlinný materiál, skaný zákrut $\mathrm{S} / 2 \mathrm{~s}$, modrá barva; b) hedvábí, skaný zákrut $\mathrm{S} / 2 \mathrm{z}$, béžová barva. Přestože se zachovaly stopy po krejčovském zpracování, původní tvar a funkci tkaniny nelze určit.

\subsection{Proužkovaná tkanina}

Zachoval se jeden fragment o rozměrech asi $1 \mathrm{~cm}$ na výšku a $25 \mathrm{~cm}$ na šířku. Hedvábné osnovní nitě a oba útky (I., II.) provazují v plátnové vazbě. Hedvábný útek I. a kovový útek II. se stř́íají a vytvářejí tak proužky.

Fragmenty jemných hedvábných tkanin v plátnové vazbě s kovovými útky se našly například v hrobech J 42, J 45, J 57, J 60, J 63, J 108 v Judendorfu-Villachu. Jsou datované do 13. století a za zemi jejich původu je označeno Španělsko. Byly zřejmě součástí ženských pokrývek hlavy (St. Martin, Villach; Petrascheck-Heim 1970, 73-77, 111-118, 122-133). Další drobný fragment hedvábné tkaniny, do které byly ve směru útku po dvou nebo po deseti prohozech zatkány kovové nitě, byl nalezen v královské hrobce ve společné rakvi, do níž byly uloženy ostatky čtyř žen Karla IV., Václava IV., první ženy Václava IV. a Jana Zhořeleckého. Jedná se zřejmě o zbytek ženské roušky, která byla utkána ve 14 . století v některé z oblastí produkce hedvábných tkanin ve Středomoří, snad ve Španělsku (Sbírky Pražského hradu, Praha; Bravermanová-Leppin-Otavská 2011, 616-617, 619). Také při archeologických výzkumech v Londýně se našel fragment tkaniny s hedvábným a pravděpodobně i kovovým útkem. Tkanina je datovaná do 14. století, provenience není uvedena (Museum of London, Londýn; Crowfoot-Pritchard-Staniland 1992, 94-96, obr. 68).

Kovovými útky proužkovaná tkanina z tumby sv. Václava může tedy pocházet ze 13.-14. století, z některé z hedvábnických oblastí ve Středomoří, asi ze Španělska.

Látka byla po směru útku střižena do proužku, jehož konce jsou svázané na uzel tak, že tvoří smyčku. Původně snad byla rouškou či liturgickým textilem a poté asi byla použita na obalení ostatku světce, o čemž by svědčilo svázání na uzel.

\subsection{Nevzorovaná tkanina v keprové vazbě}

Zachovala se v 27 fragmentech, z nichž největší má rozměry 13,3 cm na výšku a 20,8 cm na šiřrku (č. 1). ${ }^{28}$ Tkanina v keprové vazbě $2 / 1 \mathrm{~S}$ má osnovu z rostlinného materiálu (len?) a útek z vlny.

Nevzorovaná tkanina $\mathrm{v}$ keprové vazbě nevykazuje žádné znaky, podle nichž by bylo možné ji přesněji datovat či určit provenienci. Lze však předpokládat, že byla v průběhu středověku vyrobena v některé z textilních dílen v Evropě, včetně českých zemí.

$\mathrm{Na}$ některých fragmentech jsou po jedné straně zbytky lepidla, což navozuje dojem, že byla stržena z pevného podkladu. Podle nálezových okolností by se mohlo jednat o pozůstatek vlepeného látkového vyložení vnitřku gotické schrány nalezené ve vnitřním prostoru oltáře (Podlaha 1911, 30).

27 Rozměry dalších fragmentů $(\mathrm{v} \times \check{\text { s }} / \mathrm{cm}):$ č. $2: 10,4 \times 6 ;$ č. $3: 8 \times 7,3 ;$ č. $4: 3,2 \times 6,3 ;$ č. $5: 3,5 \times 7,2 ;$ č. $6: 3 \times 2,3 ;$ č. $7: 10 \times 14,3 ;$ č. $8: 5,1 \times 3,7$; č. $9: 7 \times 4,5 ;$ č. $10: 5,3 \times 3,3 ;$ č. $11: 3 \times 4,2 ;$ č. $12: 4 \times 3,2 ;$ č. $13: 3,8 \times 9,5 ;$ č. $14: 4,8 \times 4,7 ;$ č. $15: 1,5 \times 7,5 ;$ č. $16: 1,8 \times 5,3 ;$ č. $17: 5,8 \times 4,3 ;$ č. 18 : $6,3 \times 9,5 ;$ č. $19: 3,3 \times 5,6 ;$ č. $20: 2,6 \times 2,4 ;$ mnoho nepatrných fragmentů.

28 Rozměry dalších fragmentů $(\mathrm{v} \times \check{\mathrm{s}} / \mathrm{cm}):$ č. $2: 4,7 \times 18,7 ;$ č. $3: 5 \times 22,3 ;$ č. $4: 3,3 \times 24 ;$ č. $5: 5,2 \times 16 ;$ č. $6: 3,2 \times 17,6 ; \check{c} .7: 5,3 \times 19,2 ;$ č. 8 : $2,4 \times 14,5 ;$ č. $9: 2 \times 14,4 ;$ č. $10: 4,4 \times 17,8 ;$ č. $11: 3 \times 22 ;$ č. $12: 2,8 \times 20 ;$ č. $13: 6,5 \times 6,8 ;$ č. $14: 2 \times 14,5 ;$ č. $15: 3,2 \times 9,7 ;$ č. $16: 2,4 \times 11,8 ;$ č. 17 : $2,2 \times 17,2 ;$ č. $18: 2,8 \times 25,3 ;$ č. $19: 2,8 \times 19,8 ;$ č. $20: 1,3 \times 7,3 ;$ č. $21: 3 \times 9,8 ;$ č. $22: 2,8 \times 6,6 ;$ č. $23: 2,5 \times 11,3 ;$ č. $24: 2,8 \times 9,5 ; \check{c} .25: 2,2 \times 8 ;$ č. 26 : $1,3 \times 13,6$; č. $27: 1 \times 12,5$ 


\subsection{Váček na relikvie (obr. 11)}

Váček na relikvie byl ušit z jednoho obdélníkového kusu vypodšívkované tkaniny s větvičkami o rozměrech $8 \mathrm{~cm}$ na výšku a $11 \mathrm{~cm}$ na šířku. Oba delší kraje obdélníku byly v šířce asi $0,5 \mathrm{~cm}$ založeny na rubovou stranu, zastřižené okraje byly zpevněny voskem. Poté byl obdélník př́ičně přeložen na půl a po stranách sešit, šicí nit se nedochovala. Horní okraj váčku byl stažen plochou šňurkou, protaženou osmnácti prostřiženými dírkami. Po protažení šňưrky byly k ní přišity dva kulovité knoflíky, na každou stranu váčku jeden.

Zachovaný váček lze nepochybně spojit s váčkem na relikvie sv. Lazara z Betánie, sv. Ananiáše, sv. Klementa a sv. Blažeje, uvedeným v souvislosti s vnitřním prostorem oltáře (Podlaha 1911, 18). Ostatky mohly být původně zabaleny do malých kousků bílého/béžového hedvábného a modrého lněného plátna, $\mathrm{k}$ váčku zřejmě patřily i dnes oddělené malé pečeti.

Váčky na relikvie se nacházejí v mnohých sbírkách uchovávajících ostatky svatých, např́klad v souborech z kostelů sv. Serváce (St. Servatius, Maastricht; Stauffer 1991, 65-66, 78, 112-113, 117-118, 143-145, 153-154, 184, 198, 204-205, 207-209, 213, 216), sv. Michaela (St. Michael, Beromünster; Schmedding 1978, 25-26, 29-33, 44-45, 49-50), Valère (Eglise de Valère, Sion; Schmedding 1978, 269-273, 275-280, 284-288, 296-297) nebo z katedrály Nanebevzetí Panny Marie (St. Mariä Himmelfahrt, Hildesheim; Brandt-Schorta 2018, např. 31-33, 282).

\section{Tkanina s větvičkami (obr. 12)}

Jedná se o jeden kus tkaniny o výšce $8 \mathrm{~cm}$ a šířce $11 \mathrm{~cm}$. Tkanina je hedvábný lampas (dutinná tkanina $\mathrm{v}$ základu; lampas à fond double étoffe). V základu je nepravidelná atlasová vazba $5 / 1$ (décochement 5, 3, 2, 3, 2,3) tvořená hlavní osnovou a základním útkem, pod tím je oddělená vrstva v keprové vazbě $1 / 3 \mathrm{~S}$ tvořená vaznou osnovou a vzorujícím kovovým lancé útkem. Ve vzoru provazuje vazná osnova se vzorujícím útkem v keprové vazbě $1 / 3 \mathrm{~S}$, vazná osnova prochází pod základním útkem.

Obdobná technika se nachází např́iklad na italském lampasu s medvědy, psy a úponky z konce 14. nebo začátku 15. století. Vzor je tvořen dvěma lancé útky, jedním hedvábným a jedním kovovým (Deutsches Textilmuseum, Krefeld; Tietzel 1984, 331-333). Dále na lampasu pluviálu $\mathrm{s}$ heraldickými zvířaty $\mathrm{v}$ šestiúhelnících určeném jako italský z druhé poloviny 14. století, jehož vzor vytvářejí dva lancé útky, jeden hedvábný (interrompu) a jeden kovový (Dom St. Peter und Paul, Brandenburg; Jehle-Wetter 2005, 170-173).

Na hnědém pozadí tkaniny s větvičkami je zachována jen malá část zlatého vzoru stylizovaných větviček s drobnými úzkými lístky, které se po směru osnovy sbíhají a opět rozbíhají do dvou pramenů. V místě sbíhání je patrný větší rostlinný motiv. Raport vzoru nelze určit.

Obdobně stylizované větvičky s lístky jsou např́iklad na italském lampasu s ptáky a palmetami ze 14. století (Deutsches Textilmuseum, Krefeld; Tietzel 1984, 300-301). Větvičky s úzkými lístky vytvářejí zašpičatělé ovály s listy a hrozny vinné révy na dvou lampasech z Itálie z druhé poloviny 14. století (Kunstgewerbemuseum, Berlin; Wilckens 1992, 123).

Ve středověkých chrámových inventáŕích se (malá) větev vyskytuje ve formě ramusculus (k tomu Wardwell 1988-1989, 140). Tento výraz se však ve svatovítských inventářích nenalézá.

Na základě rozboru vazební techniky a vzorových analogií lze tkaninu s větvičkami určit jako italskou z druhé poloviny 14. století. Jedná se o svrchní tkaninu váčku na relikvie.

\section{Podšivka}

Jeden kus tkaniny o výšce $8 \mathrm{~cm}$ a šiřce $11 \mathrm{~cm}$, hedvábná osnova šedomodré barvy provazuje $\mathrm{s}$ útkem též šedomodré barvy ve vazbě plátnové. Jedná se o nevzorovanou podšívku váčku na relikvie. 


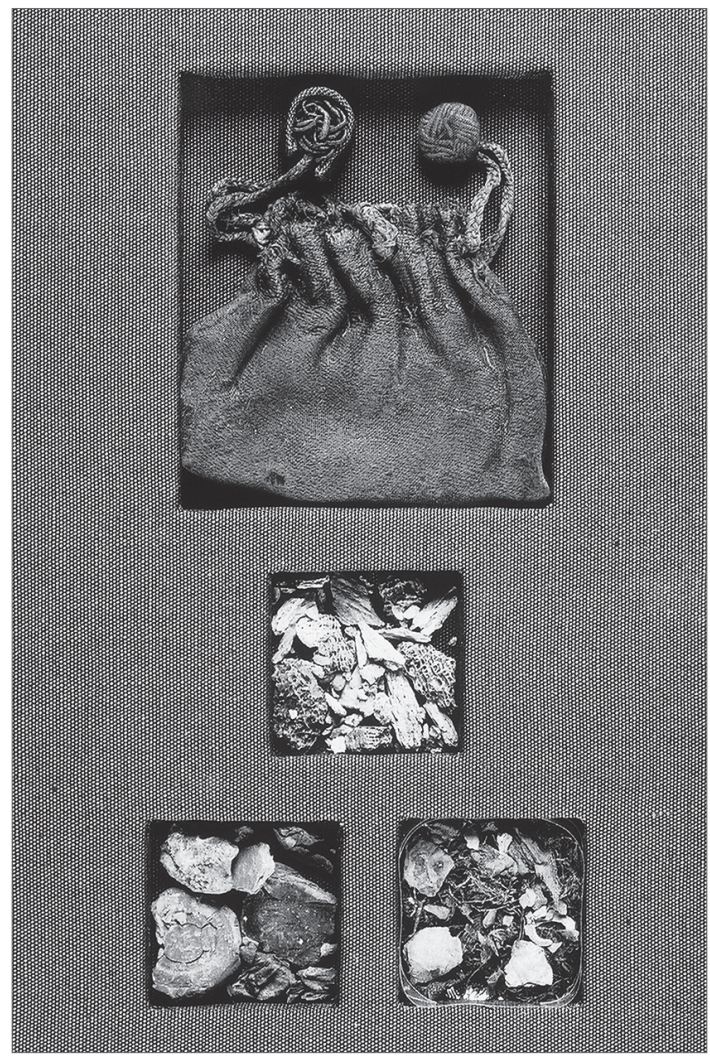

Obr. 11. Váček na relikvie. Adjustace na panelu. ( Správa Pražského hradu, foto J. Gloc.

Abb. 11. Reliquienbeutel. Montage auf einem Tableau. (C) Verwaltung der Prager Burg, Foto J. Gloc.

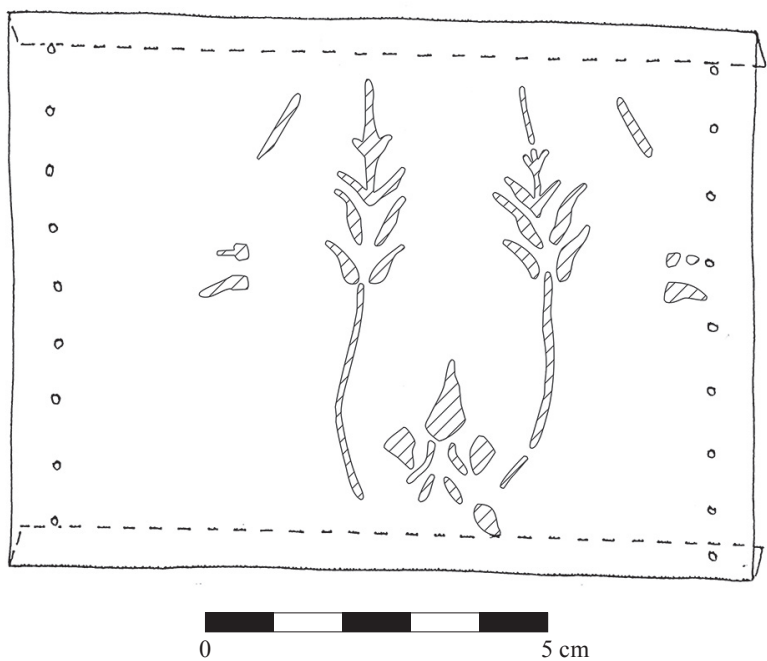

Obr. 12. Tkanina s větvičkami. Část vzoru na fragmentu. (C) Správa Pražského hradu, kresba V. Otavská.

Abb. 12. Stoff mit Zweigen. Teil des Musters auf einem Fragment. @ Verwaltung der Prager Burg, Zeichnung V. Otavská. 


\section{Šn̆ưrka}

Plochá šňůrka o délce asi $25 \mathrm{~cm}$ a šířce $0,25-0,3 \mathrm{~cm}$, která je zhotovena technikou splétání na prstech (angl. finger loop braiding) z pěti hedvábných nití modrozelené barvy. Na šňůrce je zachovaná šicí nit (hedvábí, světle béžová barva, skaný zákrut S/2 nitě bez zákrutu), jíž byly sešity dvě části šňůrky k sobě a jíž byl přišit i jeden z knoflíků.

Technikou smyčkového prstového splétání z pěti smyček byly zhotoveny dva předměty pocházející z pohřební výbavy pražského biskupa Bernarda († 1240). Jedná se o zbytek cingula a fragment šňůrky, původně zřejmě z bot (Bravermanová-Foltýn-Sliwka 2010, 7-45).

Šňůrka byla pravděpodobně spletena v souvislosti se zhotovením váčku na relikvie v Itálii ve 14. století.

\section{Knofliky}

Dva kulovité knoflíky o průměru asi $10 \mathrm{~mm}$ jsou vyrobeny propletením skupiny pěti rovnoběžně kladených hedvábných nití hnědé barvy ovinuté okolo duše z rostlinného materiálu (pravděpodobně len, z-zákrut, př́rodní barva). Možné vnitřní vyztužení knoflíků se nezachovalo.

Knoflíky byly pravděpodobně vyrobeny $\mathrm{v}$ souvislosti se zhotovením váčku na relikvie v Itálii ve 14 . století.

\subsection{Nevzorované tkaniny v plátnové vazbě}

\subsubsection{Béžová tkanina}

Nepatrné fragmenty hedvábné tkaniny. Jedná se pravděpodobně o původní obal na ostatky Z váčku na relikvie (viz 4.12).

Nevzorovaná tkanina v plátnové vazbě nevykazuje žádné znaky, podle nichž by bylo možné ji přesněji datovat či určit provenienci. Lze pouze konstatovat, že byla v průběhu středověku vyrobena v některé z hedvábnických oblastí v Asii či Evropě.

\subsubsection{Modrá tkanina}

Nepatrné fragmenty pravděpodobně lněné tkaniny. Jedná se nejspíš o původní obal na ostatky z váčku na relikvie (viz 4.12).

Nevzorovaná tkanina v plátnové vazbě nevykazuje žádné znaky, podle nichž by bylo možné ji přesněji datovat či určit provenienci. Lze však předpokládat, že byla v průběhu středověku vyrobena v některé z textilních dílen v Evropě, včetně českých zemí.

\section{Shrnutí}

Látky z tumby sv. Václava byly v letech 2002-2003 konzervovány, byl proveden textilně technologický průzkum a v letech 2018 a 2019 došlo i k novému vyhodnocení. Lze konstatovat, že současné závěry se $\mathrm{v}$ mnohém s předchozím předběžným zhodnocením $\mathrm{N}$. Bažantové shodují (1996, 19-51).

Tkaniny pocházejí z širokého období, a to od 11.-12. století (tkanina s pletencem, palmetami, perlovcem a zvířaty) až po 15. století (tkanina s palmetami; tkanina s palmetami a granátovými jablky). Největší množství jich je ze 14. století (tkanina se zašpičatělými ovály a arabským nápisem; tkanina s podélnými pruhy s palmetami, rozetami a srdčitými motivy; tkanina s kopinatými listy a medailony), př́ípadně ze 13.-14. století (tkanina s nakoso vepsanými čtverci a hvězdicemi) či z poslední třetiny 14. až začátku 15. století (tkanina s makovicemi, kachnami a lvy). Soubor doplňují přesněji nedatovatelné nevzorované tkaniny. 
Oblasti, kde byly zhotoveny, se nacházejí ve všech tehdejších hedvábnických centrech, a to ve Střední Asii, případně severní Číně (tkanina s podélnými pruhy s palmetami, rozetami a srdčitými motivy; tkanina s kopinatými listy a medailony), na Předním východě (tkanina s pletencem, palmetami, perlovcem a zvířaty), v Sýrii či Egyptě (tkanina se zašpičatělými ovály a arabským nápisem), na Předním východě, v Egyptě či islámské části Španělska (tkanina s nakoso vepsanými čtverci a hvězdicemi), Itálii (tkanina s makovicemi, kachnami a lvy), popřípadě Španělsku (tkanina s palmetami; tkanina s palmetami a granátovými jablky).

Až na nejstarší látku (tkanina s pletencem, palmetami, perlovcem a zvířaty), která byla utkána technikou samitum, byly ostatní zhotoveny technikou lampas. Nevzorované textilie byly provedeny v základních vazbách - plátnové, případně keprové.

Opět to tedy dokládá, jak bohatě byly na Pražském hradě, sídle panovníků a církevních hodnostářù, zastoupeny luxusní výrobky, což se naprríklad naposledy ukázalo při předběžném zpracování kolekce pohřebních rouch z gotické královské krypty (Bravermanová 2016, 78-114). Je významné, že po vyhodnocení tkanin z tumby sv. Václava vzrostl počet importovaných textilií z dálných asijských oblastí, tedy těch nejcennějších komodit (o středověkých hedvábných textiliích obecně Bravermanová-Březinová 2016, 113-145).

Látky pocházející z hrobu sv. Václava jsou druhotnými relikviemi, neboli předměty, které se dostaly do kontaktu s ostatky světce, a proto s nimi bylo nakládáno stejně jako s částmi světcova těla. V relikviářových schránách bývaly i po manipulacích ponechávány části původního odění světců i všechny postupně vložené tkaniny a další předměty, z nichž byly odebírány nanejvýše některé části. Ty byly poté vkládány do oltářů či rozdávány mezi věřící jako druhotné svátosti. Bylo také zvykem, že při otevírání hrobu byly ostatky znovu obaleny do dalších tkanin (Bravermanová 2010, 149).

Mnohé látky ze zkoumané kolekce jistě původně halily přímo ostatky sv. Václava. Je však zajímavé, že z 10.-11. století se žádná nedochovala, nejstarší tkaninu lze datovat až do 11.-12. století. Na rozdíl od relikviářových tkanin sv. Ludmily, kde jsou počátky souboru vročeny již do 10 . století (Bravermanová a kol. 2001, 447-486).

Tkaniny byly nalezeny ve zbytcích gotického náhrobku i v truhle umístěné pod náhrobkem. Vzhledem k tomu, že zpráva A. Podlahy (1911) není z hlediska přesného určení tkanin zcela jednoznačná, nelze stanovit, které textilní fragmenty byly tehdy vyzvednuty z prostoru zbytků nadzemní tumby a které z podzemní schrány. Tkaniny však musely být odděleny ještě před definitivním uzavřením podzemního prostoru okolo roku 1367. Z toho vyplývá, že pozdně gotické tkaniny musejí pocházet z horní části tumby, nebot' ta - na rozdíl od podzemní - byla posléze několikrát otevírána a upravována.

Většina tkanin nese stopy po krejčovském zpracování, jejich původní tvar a funkci již dnes však nelze určit. Mohly být staršími přehozy přes tumbu, oltářními přikrývkami či paramenty, jejichž části se posléze dostaly dovnitř tumby. O bohatosti výbavy katedrály sv. Víta, hrobu sv. Václava i jeho okolí se zmiňují inventáře svatovítského chrámu a svatováclavské kaple.

Nejstarší tkanina (tkanina s pletencem, palmetami, perlovcem a zvířaty) se k ostatkům mohla dostat, pokud se tak nestalo již dř́ive, v roce 1245, kdy byl oltář nad hrobem sv. Václava prokazatelně opraven a konsekrován. K románskému období a stejnému místu se vztahují i nejméně dvě další látky (červené samitum se zlatou výšivkou a červené samitum s částí vytkaného vzoru se zoomorfním motivem), které se dnes nacházejí na části tzv. př́ikrovu na hrob sv. Václava. Ten má dnes trojúhelníkový tvar a je sešit z několika samostatných tkanin datovaných od 12. do 14. století. Původně tyto látky mohly být závěsy nad Václavovým hrobem, přehozy přes tumbu či oltář nebo liturgickými rouchy (Muzeum hl. města Prahy, Praha; Bažantová 1996, 38-42).

Největší množství tkanin bylo do tumby sv. Václava připojeno až při úpravách světcova hrobu za Lucemburků. $Z$ tohoto období se dodnes také zachovala kasule a štola zvaná svatováclavská, ušité z látky datované do druhé poloviny 13. století až první poloviny 14. století. Ve svatovítských inventáŕích jsou zřejmě zmiňovány od roku 1387, kněz s právem nosit mitru však byl k oltáři nad světcovým hrobem přidělen již v roce 1378. Možná se tedy jedná přímo o paramenta tohoto kněze (Bravermanová 2012, 39). 
Samostatnou kapitolu představuje gotický váček na relikvie sv. Lazara z Betánie, sv. Ananiáše, sv. Klementa a sv. Blažeje i s několika relikviářovými tkaninami, který se do tumby sv. Václava dostal až v roce 1671. Vzhledem $\mathrm{k}$ dataci tkaniny do druhé poloviny 14. století lze říci, že se může jednat př́mo o obal, ve kterém byly ostatky v roce 1370 převezeny z Mantovy, čemuž by odpovídal i italský původ tkaniny.

Kolekce relikviářových tkanin z tumby sv. Václava patří vedle obdobné kolekce $\mathrm{z}$ tumby sv. Ludmily k těm nejvzácnějším památkám v Čechách, a to nejenom z hlediska vzácnosti luxusních látek, ale především tím, že se dostaly do těsné blízkosti ostatků nejvýznamnějšího světce a patrona českého národa.

Příspěvek byl vypracován s podporou grantového projektu GA ČR 19-00166S „Textilie z archeologických kontextů na Pražském hradě - památky po českých panovnících, jejich rodinných př́slušnících a církevních hodnostárích“.

\section{Př́loha. Textilně technologický rozbor textilií z tumby sv. Václava}

Tkanina s pletencem, palmetami, perlovcem a zvíraty (4.1, obr. 3)

Technika: samitum

Osnova

poměr: 2 hlavní osnovy ku 1 vazné osnově

- hlavní: hedvábí, z-zákrut, béžová barva

- vazná: hedvábí, z-zákrut, béžová barva

dostava: 24-32 nití/cm (hlavní osnova), 12-16 nití/cm (vazná osnova)

découpure: 2 hlavní osnovy

Útek

poměr (pořadí v passées): 1 útek I. ku 1 útku II. (I., II; II., I.) nebo 1 útek I. ku 1 útku II. ku 1 útku III. (I., II., III.; III., II., I.)

- I.: hedvábí, bez zákrutu, červenohnědá barva

- II.: pozlacený proužek živočišného podkladu obtočený kolem hedvábné duše (z-zákrut, béžová barva), směr vinutí $Z$

- III.: broché, hedvábí, bez zákrutu, zelená nebo hnědá barva

dostava: 40-45 passées/cm

découpure: 4 passées

Pevný okraj: nezachoval se

Tkanina s nakoso vepsanými čtverci a hvězdicemi (4.2, obr. 4)

Technika: lampas

Osnova

poměr: 3 páry hlavní osnovy ku 1 vazné osnově

- hlavní: hedvábí, z-zákrut, červenohnědá barva

- vazná: hedvábí, bez zákrutu, béžová barva

dostava: 33 párů nití/cm (hlavní osnova), 11 nití/cm (vazná osnova)

découpure: 3 páry hlavní osnovy

Útek

poměr (pořadí v passées): 1 základní útek ku 1 vzorujícímu útku I. ku 1 vzorujícímu útku II. nebo 1 základní útek ku 1 vzorujícímu útku I.

- základní: hedvábí, bez zákrutu, červenohnědá barva

- vzorující I.: lancé, hedvábí, bez zákrutu, béžová barva

- vzorující II.: lancé, interrompu, hedvábí, bez zákrutu, zelenobéžová barva

dostava: 9-10 passées/cm 
découpure: 1 passée

Pevný okraj: nezachoval se

Tkanina se zašpičatělými ovály a arabským nápisem (4.3, obr. 5)

Technika: lampas

Osnova

poměr: 4 páry hlavní osnovy ku 1 vazné osnově

- hlavní: hedvábí, z-zákrut (výjimečně s-zákrut), zelenomodrá barva

- vazná: hedvábí, slabý s-zákrut, žlutobílá barva

dostava: 96-100 párů nití/cm (hlavní osnova), 24-25 nití/cm (vazná osnova)

découpure: 4 páry hlavní osnovy

Útek

poměr (pořadí v passées): 1 základní útek ku 1 vzorujícímu útku

- základní: hedvábí, bez zákrutu, modrá barva (u fragmentů č. 5, 9, 10 hnědá barva)

- vzorující: lancé, hedvábí, bez zákrutu, žlutobílá barva

dostava: 28-35 passées $/ \mathrm{cm}$

découpure: 1 passée

Pevný okraj: nezachoval se

Tkanina s podélnými pruhy s palmetami, rozetami a srdčitými motivy (4.4, obr. 6)

Technika: lampas

Osnova

poměr: 5 hlavních osnov ku 1 vazné osnově

- hlavní: hedvábí, z-zákrut, béžová, béžovozelená barva

- vazná: hedvábí, bez zákrutu, béžová barva

dostava: 75 nití/cm (hlavní osnova), 15 nití/cm (vazná osnova)

découpure: 5 hlavních osnov

Útek

poměr (pořadí v passées): 1 základní útek ku 1 vzorujícímu útku

- základní: liseré, hedvábí, bez zákrutu, béžová barva

- vzorující: lancé, pozlacený proužek živočišného podkladu; dochováno fragmentárně

dostava: 17-18 passées/cm

découpure: 1 passée

Pevný okraj: nezachoval se

Tkanina s kopinatými listy a medailony (4.5, obr. 7)

Technika: lampas

Osnova

poměr: 4 hlavní osnovy ku 1 vazné osnově

- hlavní: hedvábí, z-zákrut, zelenošedá barva

- vazná: hedvábí, z-zákrut, béžovošedá barva

dostava: 68 nití/cm (hlavní osnova), 17 nití/cm (vazná osnova)

découpure: 4 hlavní osnovy

Útek

poměr (pořadí v passées): 1 základní útek ku 1 vzorujícímu útku I. ku 1 vzorujícímu útku II.

- základní: hedvábí, z-zákrut, zelenošedá barva

- vzorující I.: lancé, hedvábí, bez zákrutu, béžovošedá barva

- vzorující II.: lancé, pozlacený proužek živočišného podkladu (kůže?), dochováno fragmentárně

dostava: 15-16 passées/cm

découpure: 1 passée

Pevný okraj: zachoval se na jedné straně fragmentu č. 2 
šířka: $0,8 \mathrm{~cm}$

vazba: keprová 3/1 S (osnova I. a základní útek), plátnová vazba (osnova II., základní útek a vzorující útek I.) osnova I.: většinou zdvojená, hedvábí, z-zákrut, béžovošedá barva osnova II.: většinou zdvojená, hedvábí, z-zákrut, béžovošedá barva

Tkanina s makovicemi, kachnami a lvy (4.6, obr. 8)

Technika: lampas, dutinná tkanina v základu (lampas à fond double étoffe)

Osnova

poměr: 3 hlavní osnovy ku 1 vazné osnově

- hlavní: hedvábí, s-zákrut, béžová barva

- vazná: hedvábí, bez zákrutu, béžová barva

dostava: 42 nití/cm (hlavní osnova), 14 nití/cm (vazná osnova)

découpure: 2 hlavní osnovy

Útek

poměr (pořadí v passées): 1 základní útek ku 1 vzorujícímu útku I. ku 1 vzorujícímu útku II. nebo 1 základní útek ku 1 vzorujícímu útku III.

- základní: hedvábí, bez zákrutu, béžová barva

- vzorující I.: lancé, interrompu, hedvábí, bez zákrutu, šedomodrá barva

- vzorující II.: lancé, interrompu, hedvábí, bez zákrutu, žlutobílá barva

- vzorující III.: broché, pozlacený proužek živočišného podkladu obtočený kolem lněné duše (s-zákrut, př́rodní barva), směr vinutí S; dochováno fragmentárně

dostava: 14-18 passées/cm

découpure: 1 passée

Pevný okraj: nezachoval se

Tkanina s palmetami (4.7, obr. 9)

Technika: lampas

Osnova

poměr: 3 páry hlavní osnovy ku 1 vazné osnově

- hlavní: hedvábí, z-zákrut, červenohnědá barva

- vazná: hedvábí, bez zákrutu, béžová barva

dostava: 33-36 párů nití/cm (hlavní osnova), 11-12 nití/cm (vazná osnova)

découpure: 3 páry hlavní osnovy

Útek

poměr (pořadí v passées): 1 základní útek ku 1 vzorujícímu útku

- základní: hedvábí, bez zákrutu, červenohnědá barva

- vzorující: lancé, hedvábí, bez zákrutu, béžová barva

dostava: 10-13 passées/cm

découpure: 1 passée

Pevný okraj: nezachoval se

Tkanina s palmetami a granátovými jablky (4.8, obr. 10)

Technika: lampas

Osnova

poměr: 3 páry hlavní osnovy ku 1 vazné osnově

- hlavní: hedvábí, z-zákrut, hnědočervená barva

- vazná: hedvábí, bez zákrutu, béžová barva

dostava: 33-39 párů nití/cm (hlavní osnova), 11-13 nití/cm (vazná osnova)

découpure: 3 páry hlavní osnovy

Útek

poměr (pořadí v passées): 1 základní útek ku 1 vzorujícímu útku 
- základní: hedvábí, bez zákrutu, červenohnědá barva

- vzorující: lancé, hedvábí, bez zákrutu, béžová barva

dostava: 13 passées/cm

découpure: 1 passée

Pevný okraj: zachoval se na jedné straně fragmentů č. 1, 2

šiřka: $1,4 \mathrm{~cm}$

vazba: keprová 2/1 S (osnova I., základní útek) a plátnová vazba (osnova II., základní útek, vzorující útek) osnova I.: zdvojená, hedvábí, z-zákrut, béžová barva

osnova II.: zdvojená, hedvábí, z-zákrut, béžová barva

\section{Růžovohnědá tkanina (4.9.1)}

Tkalcovská vazba: plátnová

Osnova

hedvábí, z-zákrut, růžovohnědá barva

dostava: 32-42 nití/cm

Útek

hedvábí, bez zákrutu, růžovohnědá barva

dostava: 17-21 nití/cm

Pevný okraj: zachoval se na jedné straně

šírka: $0,4 \mathrm{~cm}$

vazba: plátnová

osnova I.: hedvábí, z-zákrut, růžovohnědá barva; od kraje: 1 osminásobná, 2 zdvojené, 25 většinou jednoduchých nití

\section{Hnědá tkanina (4.9.2)}

Tkalcovská vazba: plátnová

Osnova: hedvábí, z-zákrut, hnědá barva; dostava: 37 nití/cm

Útek: hedvábí, bez zákrutu, hnědá barva; dostava: 31-39 nití/cm

Pevný okraj: zachoval se na jedné straně fragmentu č. 1: šířka: $0,1 \mathrm{~cm}$

vazba: plátnová

osnova I.: hedvábí, z-zákrut, hnědá barva; od kraje: 2 vícenásobné, 2 zdvojené nitě

\section{Béžová tkanina (4.9.3)}

Tkalcovská vazba: plátnová

Osnova: hedvábí, z-zákrut, béžová barva; dostava: 36-39 nití/cm

Útek: hedvábí, bez zákrutu, béžová barva; dostava: 26-39 nití/cm

Pevný okraj: zachoval se na jedné straně fragmentu č. 1: šiřka: $0,05 \mathrm{~cm}$

vazba: plátnová

osnova I.: hedvábí, z-zákrut, hnědá barva; 1 vícenásobná nit

\section{Oranžovočervená tkanina (4.9.4)}

Tkalcovská vazba: plátnová

Osnova

hedvábí, bez zákrutu, oranžovobéžová až červená barva

dostava: $35-38$ nití/cm

Útek

hedvábí, bez zákrutu, oranžovohnědá až červená

dostava: 42-52 nití/cm

Pevný okraj: zachoval se na obou stranách (a,b) fragmentů č. 8, 13, 14, 15, 16, 20, ne však najednou na jednom fragmentu

šírka: okraj (a) 0,1-0,2 cm; okraj (b) 0,3-0,4 cm 
vazba: plátnová

osnova I.: hedvábí, z-zákrut, oranžovohnědá až červená; okraj (a): 4 vícenásobné; okraj (b): 12 vícenásobných nití

Proužkovaná tkanina (4.10)

Tkalcovská vazba: plátnová

Osnova (?)

hedvábí, bez zákrutu, béžová barva

dostava: 11 nití/cm

Útek (?)

- I. útek

hedvábí, slabý s-zákrut, béžová barva

- II. útek

materiál: pozlacená lamela ovinutá okolo hedvábné duše (z-zákrut, béžová barva), směr vinutí S

dostava: neurčitelná (vyšší než u osnovních nití)

Pevný okraj: nezachoval se

Nevzorovaná tkanina v keprové vazbĕ (4.11)

Tkalcovská vazba: keprová $2 / 1 \mathrm{~S}$

Osnova

rostlinný materiál (len?), z-zákrut, béžová barva

dostava: 16-23 nití/cm

Útek

vlna, z-zákrut, šedozelená barva

dostava: 16-20 nití/cm

Pevný okraj: zachoval se na jedné straně fragmentů č. 1, 5, 6, 7, 10, 13, 17, 22, 26

vazba: keprová $2 / 1 \mathrm{~S}$

osnova I.: rostlinný materiál (len?), z-zákrut, béžová barva; 1 silnější nit

Váček na relikvie (4.12, obr. 11)

Tkanina s větvičkami (obr. 12)

Technika: lampas, dutinná tkanina v základu (lampas à fond double étoffe)

Osnova

poměr: 3 páry hlavní osnovy ku 1 vazné osnově

- hlavní: hedvábí, z-zákrut, hnědá barva

- vazná: hedvábí, slabý s-zákrut, př́rodní barva

dostava: 45 párů nití/cm (hlavní osnova), 15 nití/cm (vazná osnova)

découpure: 2 páry hlavní osnovy

Útek

poměr (pořadí v passées): 2 základní útky ku 1 vzorujícímu útku

- základní: hedvábí, bez zákrutu, hnědá barva

- vzorující: lancé, pozlacený proužek živočišného podkladu obtočený kolem lněné duše (skaný S/2 nitě bez zákrutu, přírodní barva), směr vinutí S; dochováno v nepatrných zbytcích

dostava: 17 passées/cm

découpure: 1 passée

Pevný okraj: nezachoval se

Podšivka

Tkalcovská vazba: plátnová

Osnova (?) 
hedvábí, z-zákrut, šedomodrá barva

dostava: asi 60 nití/cm

Útek (?)

hedvábí, bez zákrutu, šedomodrá barva

dostava: 22 nití/cm

Pevný okraj: nezachoval se

\section{Šn̆ůrka}

technika: splétání na prstech z pěti nití, jednoduché splétání 1/1 plátno

materiál: hedvábí, z-zákrut, modrozelená barva, zdvojené až zněkolikanásobené nitě

Nevzorované tkaniny v plátnové vazbě (4.13)

Béžová tkanina (4.13.1)

Tkalcovská vazba: plátnová

Osnova (?)

hedvábí, z-zákrut, bílá až béžová barva

dostava: asi 50 nití/cm

Útek (?)

hedvábí, bez zákrutu, světle béžová barva

dostava: 35 nití/cm

Pevný okraj: nezachoval se

Modrá tkanina (4.13.2)

Tkalcovská vazba: plátnová

Osnova (?)

rostlinný materiál (pravděpodobně len), z-zákrut, modrá barva

dostava: 11 nití/cm

Útek (?)

rostlinný materiál (pravděpodobně len, z-zákrut, modrá barva

dostava: 11 nití/cm

Pevný okraj: nezachoval se

\section{Prameny}

BENEŠ KRABICE Z WEITMILE: Beneš Krabice z Weitmile, Fontes rerum bohemicarum V. (Emler, J., ed.), 457-548. Praha 1884.

BLÁHOVÁ, E.-KONZAL, M., 1976: Staroslověnské legendy českého původu. Praha.

DRUHÉ POKRAČOVÁNÍ KOSMOVO: Druhé pokračování Kosmovo. Fontes rerum bohemicarum II. (Emler, J., ed.), 270-370. Praha 1874.

ERŠIL, J.-PRAŽÁK, J., 1956: Archiv metropolitní kapituly. I. Katalog listin a listů z doby předhusitské $(-1419)$. Praha.

GUMPOLDŮV ŽIVOT VÁCLAVA KNÍŽETE ČESKÉHO: Gumpoldův život Václava knížete českého. Fontes rerum bohemicarum I. (Emler, J., ed.), 146-166. Praha 1873.

LETOPIS VINCENCIA, KANOVNÍKA KOSTELA PRAŽSKÉHO: Fontes rerum bohemicarum II. (Emler, J., ed.), 407-460. Praha 1874.

LUDVÍKOVSKÝ, J., 1958: Nově zjištěný rukopis legendy Crescente fide a jeho význam pro datování Kristiána, Listy filologické 81, 58-63.

KOSMAS: Die Chronik der Böhmen des Cosmas von Prag. Monumenta Germaniae Historica, Scriptores rerum Germanicarum, Nova series (Bretholz, B., ed.). Mnichov 1980. 
PEKAŘ, J., 1906: Die Wenzels- und Ludmila-legenden und die Echtheit Christians. Praha.

UTRPENÍ SV. VÁCLAVA MUČEDNÍKA: Utrpení sv. Václav a mučedníka. Fontes rerum bohemicarum I. (Emler, J., ed.), 183-190. Praha 1873.

VAVŘINCE, MNICHA SV. BENEDIKTA UTRPENÍ SV. VÁCLAVA: Vavřince, mnicha sv. Benedikta Utrpení sv. Václava. Fontes rerum bohemicarum I. (Emler, J., ed.), 167-182. Praha 1873.

\section{Literatura}

BAŽANTOVÁ, N., 1996: Svatováclavské textilní památky, Listy filologické, 1-4, 19-51.

BECKOVSKÝ, J., 1880: Poselkyně starých př́iběhů českých. Praha.

BERGHAUER, J. T. A., 1736: Proto-martyr poenitentiae ejusque sigilli custos semper fidelis divus Joannes Nepomucenus I. Augsburg.

- 1761: Proto-martyr poenitentiae ejusque sigilli custos semper fidelis divus Joannes Nepomucenus II. Augsburg. BOHÁČOVÁ, I., 2010: Stará Boleslav a odraz duchovní kultury v archeologických pramenech - Stará Boleslav and Reflection of Spiritial Culture in Archaelogical Evidence. In: Svatý Václav. Na památku 1100. výročí narození knížete Václava svatého (Kubín, P., ed.), 167-192. Praha.

BRANDT, M.-SCHORTA, R., edd., 2018: Der Hochaltar des Hildesheimer Dome sund sein Reliquienschatz. Band 2: Katalog und Quellen. Regensburg.

BRAVERMANOVÁ, M., 2006: Textil nejstarších Přemyslovců. In: České země v raném středověku (Sommer, P., ed.), 193-213. Praha.

- 2010: Osudy hrobu svatého Václava. In: Svatý Václav. Na památku 1100. výročí narození knížete Václava svatého (Kubín, P., ed.), 139-167. Praha.

- 2012: Kasule a štola zvaná svatováclavská. In: Svatovítský poklad. Katalog stálé výstavy v kapli sv. Kř̌́že na Pražském hradě (Kyzourová, I., ed.), 41. Praha.

-2016: Pražský hrad jako pohřebiště lucemburské dynastie. Prague Castle as the burial site of the Luxembourg dynasty. In: Koruna království. Katedrála sv. Víta a Karel IV. - The Crown of the Kingdom. Charles IV and the Cathedral of St. Vitus (Bravermanová, M.-Chotěbor, P., edd.), 78-114. Praha.

BRAVERMANOVÁ, M. a kol., 2017: Bravermanová, M.-Brabcová, T.-Odstrčilová, S.-Prajzlerová, A.Vrabcová, A., Nové poznatky o pohřebním rouchu Karla IV. z královské krypty v katedrále sv. Víta - Neue Erkenntnisse über das Begräbnisgewand Karl IV. aus der königlichen Krypta in der St.-Veits-Kathedrale. In: Oděv a textil v životě člověka doby lucemburské. Sborník př́íspěvků ze specializované konference, uspořádané národním památkovým ústavem, územním odborným pracovištěm středních Čech v Praze 6. ř́ijna 2016 (Nachtmannová, A.-Klapetková, O., edd.), 17-40. Praha.

BRAVERMANOVÁ, M.-BŘEZINOVÁ, H., 2016: Hedvábné textilie. In: Březinová, H.-Kohout, D. a kol., Středověké textilní a barvířské technologie. Soubor textilních fragmentů z odpadních vrstev z Nového Města pražského, 113-145. Praha.

BRAVERMANOVÁ, M.-BŘEZINOVÁ, H., 2017: Archaeological Textile Research in the Czech Republic. In: Archaeological Textiles - Links Between Past and Present. NESAT XIII. (Bravermanová, M.-Březinová, H.-Malcolm-Davies, J., edd.), 11-17. Liberec - Praha.

BRAVERMANOVÁ, M.-BŘEZINOVÁ, H.-URBANOVÁ, K., 2011: Metodika výzkumu archeologických textilních nálezů, ZPP 71, 97-104.

BRAVERMANOVÁ, M.-FOLTÝN, D.-SLIWKA, A., 2010: Mitra z hrobu „ctihodného Bernarda, biskupa pražského“ - The mitre from the grave of „venerable Bernard, the Prague bishop“, Medievalia historica Bohemica 13, 7-45.

BRAVERMANOVÁ, M.-LEPPIN, B.-OTAVSKÁ, V., 2011: Fragment pohřebních šatů a závoj, tzv. kruseler, z rakve českých královen z královské hrobky v katedrále sv. Víta - Das Fragment eines Begräbniskleides und ein Schleir, ein sog. Kruseler, aus dem Sarg böhmischer Königinnen aus der Königsgruft im St. Veitsdom, AH 36, 593-625.

BRAVERMANOVÁ, M.-OTAVSKÁ, V., 2000: Románská tkanina z královské hrobky na Pražském hradě Ein romanisches Gewebe aus der königlichen Gruft, AH 25, 405-428. 
BRAVERMANOVÁ, M. a kol., 2001: Bravermanová, M.-Otavská, V.-Sliwka, A.-Beneš, J.-Kopecká, I.Mazura, I., Nové poznatky o nejstarších textiliích z hrobu sv. Ludmily - Neue Erkenntisse von den ältesten Textilien aus dem Relikviengrab der Heiligen Ludmila, AH 26, 447-486.

CIBULKA, J., 1934: Václavova rotunda sv. Víta. In: Svatováclavský sborník. Na památku 1000. výročí smrti knížete Václava svatého, 230-686. Praha.

CROWFOOT, E.-PRITCHARD, F.-STANILAND, K., 1992: Textiles and clothing (c. 1150 - c. 1450). Medieval finds from excavations in London. London.

FALKE von, O., 1921: Kunstgeschichte der Seidengewebes. Berlin.

FROLÍK, J. a kol., 2000: Frolík, J.-Maříková-Kubková, J.-Růžičková, E.-Zeman, A., Nejstarší sakrální architektura na Pražském hradě. Výpověd' archeologických pramenů. Praha.

FIRCKS von, J., 2008: Liturgische Gewänder des Mittelalters aus St. Nikolai in Stralsund, 137-143. Bern, Abegg-Stiftung.

HELMECKE, G., 2001: Byzantinische und orientalische Seidenstoffe. Grabfunde aus der Sepultur der Bamberger Domherren. Bamberg.

HILBERT, K., 1934: O nálezech rotundy Václavovy. In: Svatováclavský sborník. Na památku 1000. výročí smrti knížete Václava svatého, 220-230. Praha.

HRDINA, K.-BLÁHOVÁ, M., 1972: Kosmova Kronika česká. Praha.

CHALOUPECKÝ, V., 1939: Prameny X. století. Legendy Kristiánovy o svatém Václavu a svaté Ludmile. Svatováclavský sborník II/2. Praha.

JEHLE, M.-WETTER, E., edd., 2005: Liturgische Gewänder und andere Paramante im Dom zu Brandenburg. Abegg-Stiftung, Domstift Brandenburg.

KRÁLÍK, O., 1969: Nejstarší legendy Přemyslovských Čech. Praha.

KUBÍN, P., 2011: Sedm přemyslovských kultů. Seven Přemyslid cults. Praha.

KUBÍNOVÁ, K., 2018: Cim 2: Rukopis mezi zeměmi a staletími středověké Evropy. Praha.

MARKOWSKY, B., 1976: Europäische Seidengewebe des 13.-18. Jahrhunderts. Kataloge des Kunstgewerbemuseums. Köln.

MUTHESIUS, A., 1997: Byzantine silk weawing ad 400 to 1200. Vienna.

MÜLlER-CHRISTENSEN, S., 1960: Das Grab des Papstes Clemens II. im Dom zu Bamberg. München.

OTAVSKÁ, V., 2003: Zpráva o textilně technologickém a konzervátorském průzkumu relikviářových tkaniny sv. Václava. Nepublikovaná restaurátorská zpráva uložená v dokumentaci oddělení uměleckých sbírek Správy Pražského hradu, inv. č. PHA 2.

OTAVSKÝ, K.-SALÍM, M. A. M., 1995: Mittelalterliche Textilien I. Aegypten, Persien und Mesopotamien. Spanien und Nordafrika. Bern, Abegg-Stiftung.

OTAVSKÝ, K.-WARDWELL, A. E., 2011: Mittelalterliche Textilien II. Zwischen Europa und China. Bern, Abegg-Stiftung.

PEŠINA Z ČECHORODU, T., 1673: Phosphorus septicornis, stella alias matutina. Hoc est: Sanctae metropolitanae Divi Viti ecclesiae Pragensis Majestas et Gloria, qiubus illa per tot saecula orbi nostri enituit semper clarissima. Praha.

PETRASCHECK-HEIM, I., 1970: Die Goldhauben und Textilie der hochmittelalterlichen Gräber von Villach-Judendorf. In: Neues aus Alt-Villach. Museum der Stadt Villach. Jahrbuch 7, 57-190. Villach.

PODLAHA, A., 1911: Sv. Václava hrob a ostatky. Praha.

- 1834: Hrob svatého Václava. In: Svatováclavský sborník. Na památku 1000. výročí smrti knížete Václava svatého, 130-158. Praha.

PODLAHA, A.-ŠITTLER, E., 1903: Chrámový Poklad u Sv. Víta v Praze. Praha.

SCHMEDDING, B., 1978: Mittelalterliche Textilien in Kirchen und Klöstern der Schweiz. Bern, Abegg-Stiftung. SOMMER, P., 2000: Smrt kněžny Ludmily a začátky české sakrální architektury, ČČH 2, 229-260.

SPITTEL, K., 2002: Fragmente aus dem Grab des Heiligen Wenzel. Nepublikovaná restaurátorská zpráva uložená v dokumentaci oddělení uměleckých sbírek Správy Pražského hradu, inv. č. PHA 2.

STÁTNÍ RESTAURÁTORSKÉ ATELIÉRY, 1985: Restaurátorská zpráva. Nepublikovaná restaurátorská zpráva uložená v dokumentaci oddělení uměleckých sbírek Správy Pražského hradu, inv. č. PHA 2.

STAUFFER, A., 1991: Die mittelalterlichen Textilien von St. Servatius in Maastricht. Bern, Abegg-Stiftung. 
TIETZEL, B., 1984: Italienische Seidengewebe des 13., 14. und 15. Jahrhunderts. Deutsches Textilmuseum Krefeld. Köln.

TŘEŠTÍK, D., 1997: Počátky Přemyslovců. Vstup Čechů do dějin (530-935). Praha.

- 2002: Dynastičtí svatí a zemští patroni: Václav, Ludmila, Vojtěch. In: Střed Evropy okolo roku 1000. Svazek esejí 1, svazek esejí 2, katalog (Wieczorek, A.-Hinz, H.-M., vyd.), 314-315. Praha.

YARZA LUACES J., ed., 2005: Vestiduras ricas. El Monasterio de las Huelgas y su época 1170-13. Catálogo de la Exposición. Patrimonio Nacional. Madrid.

WARDWELL, A. E., 1988-1989: Panni Tartarici: Eastern Islamic silks woven with gold and silver (13th and 14th centuries), Islamic Art. An Annual dedicated to the Art and Culture of the Muslim World III, 94-173.

WILCKENS von, L., 1991: Die textilen Künste. Von der Spätantike bis um 1500. München.

- 1992: Mittelalterliche Seidenstoffe. Bestandskatalog XVIII des Kunstgewerbemuseums. Berlin.

ZEMINOVÁ, M., 1987: Textilie. In: Kol. autorů, Středověké umělecké řemeslo ze sbírek Uměleckoprůmyslového muzea v Praze, 46-54. Praha.

ZHAO FENG, 1999: Treasures in silk. Hong Kong.

\section{Zusammenfassung}

\section{Die Textilien aus der Tumba des hl. Wenzel}

In den Sammlungen der Prager Burg wird eine wertvolle Kollektion von Textilien aufbewahrt, die aus der Tumba des hl. Wenzel († 935) stammt. Die Gebeine des Fürsten wurden einige Jahre nach seinem Tod aus Stará Boleslav, wo der hl. Wenzel ermordet wurde, auf die Prager Burg überführt und in der Südapsis der St. Wenzel-Rotunde niedergelegt. Im Jahr 1060 wurde die Rotunde zu einer romanischen Basilika umgebaut, und im Jahr 1344 wurde an dieser Stelle mit dem Bau einer gotischen Kathedrale begonnen. Das Wenzelsgrab befand sich nach Jahrhunderten jedoch immer noch an derselben Stelle und wurde lediglich umgestaltet. Im Mittelalter kam es zur Errichtung einer schmuckvollen oberirdischen Tumba und eines Altars, deren Verzierungen letztendlich jedoch zerstört wurden. Im Jahr 1911 wurde die Tumba geöffnet, wobei auch ihre Umgebung untersucht wurde. Die Gebeine wurden zusammen mit dem Inventar, vor allem mit den Textilien, herausgenommen, und zwar sowohl aus dem Altar, als auch aus dem sich unterhalb des Fußbodenniveaus befindenden gotischen Bleisarg. Insgesamt 18 Stoffe wurden in den Jahren 2002-2003 restauriert, einer textil-technologischen Untersuchung unterzogen, und in den Jahren 2018 und 2019 kam es auch zu ihrer Auswertung.

Die Stoffe stammen aus einem breiten Zeitraum, und zwar vom 11.-12. Jahrhundert (Stoff mit Flechtkranz, Palmetten, Perlstab und Tieren) bis zum 15. Jahrhundert (Stoff mit Palmetten; Stoff mit Palmetten und Granatäpfeln). Die größte Menge von ihnen ist aus dem 14. Jahrhundert (Stoff mit zugespitzten Ovalen und einer arabischen Inschrift; Stoff mit Längsstreifen und Palmetten, Rosetten sowie mit herzförmigen Motiven; Stoff mit lanzettenförmigen Blättern und Medaillons; Stoff mit Zweigen), ggf. aus dem 13.-14. Jahrhundert (Stoff mit quer einbeschriebenen Quadraten und mit Sternen), bzw. aus dem letzten Drittel des 14. bis Anfang des 15. Jahrhunderts (Stoff mit Mohnköpfen, Enten und Löwen). Die Kollektion wird durch nicht genauer datierbare Stoffe ohne Muster komplettiert.

Die Gebiete, wo die Stoffe hergestellt wurden, befinden sich in allen damaligen Seidenzentren, und zwar in Mittelasien, ggf. in Nordchina (Stoff mit Längsstreifen und Palmetten, Rosetten sowie mit Herzmotiven; Stoff mit lanzettenförmigen Blättern und Medaillons), im Vorderen Orient (Stoff mit Flechtkranz, Palmetten, Perlstab und Tieren), in Syrien bzw. Ägypten (Stoff mit zugespitzten Ovalen und arabischer Inschrift), im Vorderen Orient, in Ägypten bzw. im islamischen Teil Spaniens (Stoff mit quer einbeschriebenen Quadraten und mit Sternen), in Italien (Stoff mit Mohnköpfen, Enten und Löwen; Stoff mit Zweigen), ggf. in Spanien (Stoff mit Palmetten und Granatäpfeln). 
Bis auf den ältesten Stoff (Stoff mit Flechtkranz, Palmetten, Perlstab und Tieren, der mit der Samitum-Technik gewebt wurde, wurden die Stoffe mit der Lampas-Technik hergestellt. Die Textilien ohne Muster waren in den Grundbindungen - Leinen-, ggf. Köperbindung - ausgeführt.

Bei den aus dem Wenzelsgrab stammenden Stoffen handelt es sich um Sekundärreliquien, oder um Gegenstände die mit den Gebeinen des Heiligen in Kontakt kamen, weswegen mit ihnen ebenso umgegangen wurde wie mit den Körperteilen des Heiligen. In Reliquienschreinen pflegte man auch nach Eingriffen Teile der ursprünglichen Kleidung der Heiligen und alle nach und nach hineingelegten Stoffe und weiteren Gegenstände zu belassen, von denen höchstens einige Teile entnommen wurden. Diese wurden danach in den Altar gelegt oder unter den Gläubigen als sekundäre Sakramente verteilt. Auch war es Brauch, dass man bei der Öffnung eines Grabes die Gebeine wieder in andere Stoffe gehüllt hat.

Die meisten Stoffe aus der Tumba des hl. Wenzel tragen Spuren einer Textilbearbeitung, deren ursprüngliche Form und Funktion sich heute jedoch nicht mehr bestimmen lässt. Es könnte sich um Überwürfe für die Tumba, um Altardecken oder - paramente gehandelt haben, von denen Teile schließlich in die Tumba gelangt sind und zu Hülltüchern der Gebeine wurden. Die reiche Ausstattung des Veitsdoms, des Wenzelsgrabes und seiner Umgebung findet auch in den Inventaren des Veitsdoms und der gotischen St. Wenzelskapelle Erwähnung.

Der älteste Stoff (Stoff mit Flechtkranz, Palmetten, Perlstab und Tieren) könnte - falls dies nicht früher geschah - im Jahr 1245 zu den Gebeinen gelangt sein, als der Altar über dem Wenzelsgrab nachweislich instand gesetzt und konsekriert wurde. Die größte Menge an Stoffen wurde der Tumba erst nach den Umgestaltungsarbeiten des Heiligengrabes unter den Luxemburgern hinzugefügt.

Ein eigenes Kapitel stellt der gotische Reliquienbeutel für Reliquien des hl. Lazarus von Betanien, des hl. Ananias, des hl. Clemens und des hl. Blasius sowie einige Reliquienstoffe dar und gelangte laut einem schriftlichen Bericht erst im Jahr 1671 in die Tumba des hl. Wenzel. Im Hinblick auf die Datierung des Stoffes dieses Beutels in die zweite Hälfte des 14. Jahrhunderts kann man sagen, dass es sich um das Hülltuch handeln kann, in dem die Gebeine im Jahr 1370 aus Mantua überführt wurden, was auch der italienischen Herkunft des Stoffes entspricht.

Die Kollektion der Reliquienstoffe zählt neben einer ähnlichen Kollektion aus der Tumba der hl. Ludmilla aus der St. Georgs-Basilika auf der Prager Burg zu den kostbarsten böhmischen Denkmälern, und zwar nicht nur hinsichtlich der Seltenheit der Luxusstoffe, sondern vor allem deshalb, weil sie in die dichte Nähe der Gebeine des Landespatrons des tschechischen Volkes gelangten. Nach ihrer Auswertung wird deutlich, dass sie wiederum belegen, wie reichhaltig Luxuserzeugnisse auf der Prager Burg, dem Sitz der Herrscher und geistlichen Würdenträger, vertreten waren.

Der vorliegende Beitrag wurde im Rahmen des Förderprojekts GA ČR 19-00166S „Textilien aus den archäologischen Kontexten auf der Prager Burg - Denkmäler der böhmischen Herrscher, ihrer Familienangehörigen und der geistlichen Würdenträger" ausgearbeitet.

PhDr. Milena Bravermanová, Archeologický ústav AV ČR, Praha, v. v. i., Letenská 4, Praha 1, Česká republika, milena.bravermanova@seznam.cz

PhDr. Helena Březinová, Ph.D., Archeologický ústav AV ČR, Praha, v. v. i., Letenská 4, Praha 1, Česká republika,brezinova@arup.cas.cz

Bc. Jana Bureš Víchová, restaurátorka textilu, Česká republika,jvichova@seznam.cz 
